\title{
Experimental design of the Cu-As-Sn ternary colour diagram
}

\author{
M. Radivojević a ${ }^{*}{ }^{*}$, J. Pendić ${ }^{b}$, A. Srejić ${ }^{c}$, M. Korać ${ }^{d}$, C. Davey ${ }^{e}$, A. Benzonelli ${ }^{e}$, \\ M. Martinón-Torres ${ }^{e}$, N. Jovanović d, Ž. Kamberović ${ }^{d}{ }^{* *}$ \\ ${ }^{a}$ McDonald Institute for Archaeological Research, University of Cambridge, Downing Street, CB2 3ER \\ Cambridge, UK \\ ${ }^{\mathrm{b}}$ BioSense Institute, University of Novi Sad, Zorana Đinđića 1, 21101 Novi Sad, Serbia \\ c Mei Ta Europa Industries Ltd., Železnička bb, 11500 Obrenovac, Serbia \\ d Faculty of Technology and Metallurgy, University of Belgrade, Karnegijeva 4, Belgrade, Serbia \\ e UCL Institute of Archaeology, 31-34 Gordon Square, WC1H OPY London, UK \\ * Corresponding author \\ ** Corresponding author
}

\begin{abstract}
The aesthetic appearance of metals has long been recognised in archaeometric studies as an important factor driving inventions and innovations in the evolution of metal production. Nevertheless, while studies of ancient gold metallurgy are well supported by modern research in colour characteristics of gold alloys, the colour properties of major prehistoric copper alloys, such as arsenical copper and tin bronzes, remain either largely understudied or not easily accessible to the western scholarship. A few published studies have already indicated that alloying and heat treatment change the colours of copper alloys, although they are mainly based on examples of prehistoric tin bronze objects and experimental casts. Here we present a procedure for building the Cu-As-Sn ternary colour diagram, starting with experimental casting of 64 binary and ternary alloys in this system. We used two types of information to produce two different ternary colour diagrams: one based on photographs of the samples, and the other based on the colorimetric measurements. Furthermore, we developed a procedure for creating a graphic representation of colours in the Cu-As-Sn ternary diagram using QGIS. As an initial case study, we plotted the composition of the world's earliest tin bronze artefacts; the graphic representation further supports claims about the importance of a golden hue for their invention and demand, c. 6500 years ago. We argue that the presented colour diagrams will find wide use in future investigations of aesthetics of prehistoric copper alloys.
\end{abstract}

Keywords Colour; Copper alloys; Ternary diagram; Cu-As-Sn alloys; Colorimetry; Archaeometallurgy; Composition; Voronoi cells; Tin bronze 


\section{Introduction}

The appreciation for colour has long been recognised as an important factor driving inventions and innovations in the evolution of metal production. Cyril Stanley Smith $(1975,1981)$ was among the first to recognise that technological breakthroughs (such as the invention of metallurgy) were motivated more by appreciation for colour, acoustic properties, scent, or reflectance of materials than by the pursuit for better tools or weapons. As he famously noted, the 'desire to beautify the utilitarian has always stretched the ingenuity of the mechanics' (Smith, 1981: 330). Also, archaeologists and anthropologists working with aesthetics, art and technology have acknowledged the association of distinctive colours and brilliant surfaces with ritual powers and potency (e.g. Gell, 1992; Jones and MacGregor, 2002; Chapman, 2007; Saunders, 2011).

Archaeometric studies have as well identified the importance of understanding the interaction of physical properties of materials, such as colour, and social practices involved in their manufacture (e.g. Lechtman, 1977, 1980; Jones, 2004; Thornton, 2007; Martinón-Torres et al., 2007; Martinón-Torres and Rehren, 2009; Martinón-Torres and Uribe-Villegas, 2015a; Killick and Fenn, 2012; Leusch et al., 2014; Radivojević and Rehren, 2016). For instance, the colour of black and green copper minerals has been proposed as a driving force behind the invention of copper and tin bronze metallurgy and its transmission across the Balkans in the $5^{\text {th }}$ millennium BC, while the unparalleled practice of selection of these distinctively coloured minerals supported the argument for the independent origins of Balkan metallurgy (Radivojević, 2015). Moreover, the emergence of tin bronzes in the mid $5^{\text {th }}$ millennium $B C$ in this region has been interpreted as a reaction to the demand for the colour of metal that comes closest to gold in its appearance (Radivojević et al., 2013), then a highly valued and contemporary metal that occurs in northeast Bulgaria, most notably within the Varna culture (Todorova and Vajsov, 2001; Avramova, 2002; Dimitrov, 2002; Leusch et al., 2014, 2015). In a similar vein, research into the origins of lost-wax casting in South America has highlighted the similarity of colour of the ritually important wax and the alloys cast with it (Martinón-Torres and Uribe-Villegas, 2015b), and a recent study has argued that the surface colours of Nahugange goldcopper alloys were modified in the course of their life-histories, probably responding to different cultural and ritual contexts (Sáenz-Samper and Martinón-Torres, 2017). Other relevant example include Hosler's (1994) exploration of the significance of aesthetics and sound in metal use in historic west Mexico, and of how those shaped the Mesoamerican worldview.

Nevertheless, while studies of ancient gold metallurgy are well supported by modern research in colour characteristics of Au-Ag-Cu alloys (e.g. Leuser, 1949; McDonald and Sistare, 1978; Roberts and Clarke, 1979; German et al., 1980; German, 1982; Rapson, 1990; Cretu and van der Lingen, 1999), the colour properties of major prehistoric copper alloys, such as arsenical copper and tin bronzes remain either largely understudied (but see Chase, 1994; Bourgarit, 2003; Berger et al., 2010; Berger, 2012; Fang and McDonnell, 2011; Mödlinger et al., 2017), ${ }^{1}$ or not easily accessible to western scholarship (Магницкий and Пирайнен, 1996). These studies employed colorimetric analyses and showed how alloying and heat

\footnotetext{
${ }^{1}$ The very relevant recent work by Mödlinger et al. (2017) appeared only as we were submitting the revised version of this manuscript for publication. We have therefore been unable to compare and integrate our dataset and ideas with theirs, but look forwasto doing so in the future.
} 
treatment change the colour of copper alloys, mainly based on the examples of tin bronze (prehistoric) objects and accompanying experimental casts. Namely, Magnickii and Pirainen (Магницкий and Пирайнен, 1996: 65, Тab. 2.19) indicate the change of colour of tin bronzes from copper red to pale pink with the addition of up to c. $5 \mathrm{wt} \% \mathrm{Sn}$, which then changes into a yellow hue once exceeding c. $8 \mathrm{wt} \% \mathrm{Sn}$ and finally reaches a silver colour past c. 25-30 wt\% Sn.

Fang and McDonnell (2011: 54) showed that the influence of tin on the colour of tin bronzes may be observed via two trends: 1 ) the addition of tin up to c. $15 \mathrm{wt} \%$ significantly reduces the redness of copper, while 2) past this mark and into the high-tin bronze range (c. 18-33 wt\%), the increasing tin content reduces both the redness and the yellowness of the alloy, driving it towards a more silvery colour. One of the most notable examples of exploitation of this property of high tin bronzes in the past is the production of (Chinese) mirrors (Bourgarit, 2003), usually found in burial contexts across prehistoric east Eurasia. These objects have poor mechanical properties, however, they have a distinctive colour, which together with their hardness has been argued as one of the reasons for their production (e.g. Needham, 1962; Stech and Maddin, 1988; Meeks, 1986 and literature therein).

As opposed to tin bronzes, the colour properties of arsenical copper objects have been seldom studied, although other effects of arsenic, as much as tin additions to copper for improving mechanical properties of copper alloys of archaeological interest have been addressed in much more detail (e.g. McKerrell and Tylecote, 1972; Northover, 1989; Budd, 1991; Meeks, 1993; Lechtman, 1996; Mödlinger and Sabatini, 2016). Some material properties of the Cu-As-Sn ternary system have also been investigated (Roeder and Notis, 1985, 1987; Roeder et al., 1986; Bochvar and Materials Science International Team, 1994); however, although generic references to the different hues occur in the archaeological literature, no systematic work has been carried out on the aesthetic properties of the Cu-As-Sn binary and ternary alloys.

Given the acknowledged importance of aesthetics in ancient metallurgy, we embarked on building a CuAs-Sn colour ternary diagram from 64 pellets of various compositions (Cu-As, Cu-Sn, As-Sn, Cu-As-Sn, see Tables 1 and 2) we experimentally produced in the laboratories of the Faculty of Technology and Metallurgy at the University of Belgrade. Our goal was to create a colour diagram that would have the same general use as the ternary Au-Ag-Cu colour diagram, and which would ultimately add a colour dimension to scientific pursuits on the intention behind the manufacturing of Cu-As-Sn binary and ternary alloys in the past.

\section{Materials and methods}

We built the ternary Cu-As-Sn colour diagram in four steps. The first consisted of the experimental making of 64 metal pellets with various ratios of copper, arsenic and tin (see Table 1), followed by cutting them into shape and polishing. In the second step we conducted chemical analyses of all metal pellets and photographed them under identical studio conditions. The third step included measuring colour, while in the fourth we used all acquired information to construct two types of Cu-As-Sn colour ternary diagrams: one, based on samples of original images, and the other, established on the colorimetric measurements. Lastly, we use the reported composition of the world's earliest tin bronze artefacts (Radivojević et al., 2013: 1035, Table 1), which were discovered in the Balkans and dated roughly from mid to late $5^{\text {th }}$ millennium BC, to illustrate the use of this diagram to assess claims on the importance of their golden hue for their invention and appeal. 


\subsection{Experimental production of Cu-As-Sn binary and ternary metal pellets}

All 64 samples were prepared in the Laboratory for Extractive Metallurgy at the Faculty of Technology and Metallurgy, University of Belgrade in Serbia. Each alloy carries a designated number, in our case from 2 to 70; alloys with numbers 13 , and 58-61 were either produced as duplicates (No. 13) or unsuccessfully alloyed (Nos 58-61). Hence, we present here 64 samples in total for further consideration, numbered as presented in Table 1. We used the following ingredients: electrolytic copper (99.5\%), tin granules (99.9\%) and arsenic metal (99.5\%). The main emphasis during the design of Cu-As-Sn alloy compositions was set on filling the copper rich 'corner' of the ternary diagram more densely than the ones with $100 \%$ As or $100 \% \mathrm{Sn}$. In the copper corner we projected alloy compositions with increments of 1 to $2 \mathrm{wt} \%$ for Sn and As respectively (as alloying elements) in both binary and ternary arrangements. These increments were turned into $10 \%$ steps after $30 \mathrm{wt} \% \mathrm{Sn}$ and $20 \mathrm{wt} \%$ As (see Table 1). Such design was led by our knowledge of the prehistoric copper alloys, which commonly do not contain tin above 30 wt $\%$ and arsenic past 20 $w t \%$, although there are exceptions to this rule.

In order to facilitate the melting and alloying of all three components ( $\mathrm{Cu}$, As and $\mathrm{Sn}$ ), particularly regarding the necessity to lower the melting point for copper-arsenic alloys, we prepared three master alloys: Cu-Sn (50-50\%), As-Sn (40-60\%) and Cu-As (64-36\%) and used them for the making of Sn-As, Cu-As and $\mathrm{Cu}$ - As-Sn alloys (Table 2). For the preparation of $\mathrm{Cu}$-As master alloy, we conducted the diffusion alloying process. Arsenic metal was mechanically pre-treated, including crushing and milling to obtain fine particles (200 $\mu$ min size), suitable for the melting process. This was performed as an open bath melting in SiC crucible $(\varnothing 50 \times 80 \mathrm{~mm}$ ) by alternating layers of charcoal and mixture of copper powder and arsenic in the defined ratio. All input materials (or charge) in the crucible were heated to $650{ }^{\circ} \mathrm{C}$ for $2 \mathrm{~h}$ under the constant temperature; the final product was a Cu-As metal 'sponge'.

Table 2 outlines the type of charge we used for making all binary and ternary alloys, categorised in four groups. The preparation of Cu-Sn alloys required only two components, $\mathrm{Cu}$ and $\mathrm{Sn}$, while $\mathrm{Sn}$-As was made with three in total: $\mathrm{Sn}$, As and As-Sn master alloy. The Cu-As binary alloys, on the other hand, were made with $\mathrm{Cu}, \mathrm{As}$ and $\mathrm{Cu}$-As master alloy. Finally, the ternary Cu-As-Sn alloys were prepared with all three indicated metals and Cu-Sn and As-Sn master alloys. The Cu-As master alloy was commonly added $10 \%$ in excess due to expected losses from the evaporation of arsenic. All alloys were melted in a medium frequency water-cooled induction furnace (graphite crucible $\varnothing 80 \times 100 \mathrm{~mm}$, unit power $15 \mathrm{~kW}$, utility frequency $2000 \mathrm{~Hz}$, Fig. S1), with charcoal as the reducing agent, and borax as a deoxidiser.

During the melts, the vapours from the process were treated through bag-filters and adsorption columns. The off-gases released during this process were directed through a system that comprised of a cooler and a bag filter before release to the atmosphere. The characteristics of the system are as following:

- Bag filter: 6 sleeves, $\phi=100 \times 400 \mathrm{~mm}, \mathrm{~h}=400 \mathrm{~mm}$, area $\mathrm{P}=0.7536 \mathrm{~m}^{2}$

- Cooler: $\phi=150 \times 2900 \mathrm{~mm}$, area $1.3345 \mathrm{~m}^{2}$

- Fan: gas flow $1500 \mathrm{~m}^{3} / \mathrm{h}, 2800 \mathrm{~min}^{-1}, 3 \mathrm{KW}$

The combination of graphite crucible and medium frequency furnace provided the optimal conditions for indirect heating through the crucible. The ratio of all ingredients was calculated to produce c. $100 \mathrm{~g}$ of the desired metal alloys. Each mixture, as outlined in Table 2, was added to a pre-heated graphite crucible. Upon obtaining a homogenous melt, metal pellets were cast in permanent moulds (grey iron, wall thickness $15 \mathrm{~mm}$, dimensions $150 \times 30 \times 4 \mathrm{~mm}$, height suitable for simultaneous casting of three samples 
of dimensions $30 \times 30 \times 4 \mathrm{~mm}$ ), in order to ensure that slag or oxide layers were not transferred with the melt. Depending on the type of Cu-As-Sn binary or ternary alloy, the majority of our experimentally made metal pellets were cast at temperatures between c. $700{ }^{\circ} \mathrm{C}$ and c. $1100{ }^{\circ} \mathrm{C}$ (Fig. 1, Table 1). Casting was conducted at temperatures c. $45-50{ }^{\circ} \mathrm{C}$ above the indicated liquidus; the overheating was done to enable suitable conditions for casting.

The permanent moulds were designed bearing in mind casting temperature, sample size, number of casts per mould and the cost of the mould material. Prior to casting, we coated the moulds with beeswax to form a thin barrier between the melt and the mould. The coating of moulds was necessary for several reasons: preventing the premature solidification of metal, enabling suitable rate and direction of solidification, obtaining favourable final structure, reducing thermal shock and preventing the erosion of moulds with liquid metal. After we applied the beeswax, each mould was heated using a gas burner for removal of excess moisture at temperatures between 150 and $200{ }^{\circ} \mathrm{C}$. During heating of the moulds to the mentioned temperatures range, partial evaporation of beeswax occurred (the temperature of beeswax evaporation is $204{ }^{\circ} \mathrm{C}$ ); this left a thin film on the inner surface of the moulds that prevented premature solidification of metal and at the same time stopped the metal from sticking to the mould, hence facilitating its subsequent extraction for further study.

After casting, the metal samples were cooled in the moulds for 3-4 min, removed from them and then left to cool in air atmosphere for another $30 \mathrm{~min}$ (when their temperature reached approximately $200{ }^{\circ} \mathrm{C}$ ), before they were intensively cooled with water spraying. Such a cooling regime aimed at preserving the metal homogeneity (cf. Srejić, 2015). We produced a total of 64 samples: 43 binary alloys (30 Cu-Sn, $8 \mathrm{Cu}$ As, $5 \mathrm{Sn}$-As) and 21 ternary alloys in the $\mathrm{Cu}$-As-Sn system (Table 3). Once the samples were cooled, we cut them into sizeable pellets (roughly $3 \times 3 \mathrm{~cm}$ ) with a handsaw, and ground them using abrasive discs (3001200 grit), rinsing with water between each grinding stage.

\subsection{Chemical analysis and photographing}

All 64 samples were analysed for their chemical composition with a handheld pXRF (Olympus InnovX Delta Premium, working conditions $40 \mathrm{kV}$ for $30 \mathrm{~s}$, Alloy Plus setup). Each pellet was measured three times, and the average (gained and projected) values are presented in Table 1; absolute and relative differences between the projected and gained compositions, are included in Table 4. Freshly polished samples (down to 1200 grit) were photographed immediately with a macro lens attached to a Canon digital camera under identical conditions in a dark room, using diffused flash. These conditions were deemed the optimal solution for obtaining images of metal pellets with significantly reduced specular reflection.

\subsection{Colorimetry}

In preparation for colorimetry, pellets were polished using silicon carbide ( $\mathrm{SiC}$ ) paper (down to 4000 grit) and water lubricant, unless they contained $\geq 90 \%$ copper or tin, in which case paraffin wax was used as a lubricant to trap the SiC particles so they did not embed in the soft metal surface and affect colour measurements. We took colorimetric measurements at the Department of Scientific Research at the British Museum, using a Minolta CM-2600D hand-held spectrophotometer ( $d / 8^{\circ}$ geometry) with integration sphere and ultraviolet filter, with a $3 \mathrm{~mm}$ measurement aperture. To measure the 'true' colour of the pellets as well as the appearance of their colour, we used two common measurement modes of the instrument: Specular Component Included (SCI) and Specular Component Excluded (SCE). While SCl includes both specular and diffuse reflected light to collect measurements unaffected by any surface conditions, the SCE mode excludes any specular reflected light in order to remain sensitive to surface 
condition. We collected both $\mathrm{SCl}$ and SCE data, but here we report only measurements including the specular reflection $(\mathrm{SCl})$, since they are most commonly used to meet colour quality standards. A detailed comparison of the impact of different measurement conditions for the colorimetric analysis of copper alloys will be presented in a subsequent publication. The instrument was calibrated with two reference points (zero and standard white). Five colour measurements were taken on each of the metallic samples, using a D65 illuminant and a $10^{\circ}$ standard observer setting.

While average colorimetric values are reported and used for the ternary diagrams below (Table 5), all five results are presented for the copper-tin pellets in Table S1 to illustrate the precision range of the colour measurements. No certified colorimetric standards were available in this project and metal porosity did affect measurements, especially the $L^{*}$ values, so questions remain about the overall precision and accuracy of colorimeter measurements and the role of porosity in colour. Error rates are increased for colours with very low CIELAB measurements, such as black and white, as the limit of detection is approached for that colorimeter.

Because surface texture affects light reflection (Yonehara et al., 2004), colour measurements were taken making sure that the polishing scratches were all the same orientation. All results were obtained for the CIELAB colour space model, collecting values for L* (lightness), a*(red/green value) and b* (yellow/blue value); this model is most commonly used to measure human colour perception based on the opponentcolours theory (cf. Hunter and Harold, 1987; Shah and Gandhi, 1990). The mean colorimetric values are reported in Table 5 together with their conversion to RGB, obtained through freely available colour converter algorithms. ${ }^{2}$

Finally, we used the (gained) compositional analyses, images and colorimetric (converted into RGB, see Table 5) values in the fourth and final stage to create a graphic representation of colours in the Cu-As-Sn ternary diagram in QGIS, an open source Geographic Information System. All images used for making the Cu-As-Sn ternary diagrams have been stored online as high resolution files on Apollo, the University of Cambridge Research Repository, and can be accessed via the following link: https://doi.org/10.17863/CAM.12524.

\section{Results and discussion}

\subsection{Building the Cu-As-Sn ternary colour diagrams}

Two sets of data were included in the building of Cu-As-Sn colour ternary diagrams: segments of images (or 'textures') and colorimetric values (Table 5). By 'texture' we refer here to the surface of metal pellets 'as is', or more precisely, as they were at the time of photographing under controlled photo studio conditions described above. Hence, segment sampling plainly refers to 'cutting out' segments of images in the image editor (Photoshop CS6) and planting them in the designated spaces (see procedure below) in the Cu-As-Sn ternary diagram in order to show the colour representation of all produced pellets as photographed. When it comes to $100 \%$ As, we used an image of pure arsenic metal retrieved online ${ }^{3}$ to sample texture and RGB values (Table 5). This point is marked as No. 71, and represents the only metal sample that we did not produce. Overall, our goal was to create two types of graphic representations: 1 )

\footnotetext{
${ }^{2}$ https://nixsensor.com/free-color-converter/ (to check results we also used https://www.easyrgb.com/en/convert.php).
} 
ternary diagrams with original textures of Cu- As-Sn binary and ternary metal alloys and 2) ternary diagrams with colorimetric values of the said samples.

We projected all compositional values of our alloys (Table 1) as dots onto the Cu-As-Sn ternary diagram (see example for the Cu corner cut at 30\% Sn and 30\% As in Fig. 2), which was drawn as a single workspace in QGIS. In order to enhance the visibility of our alloys in the diagram, and to offer a solution for systematic charting for similar research in the future, we used the ternary diagram space as a canvas upon which colours of corresponding alloys were applied through the Voronoi diagrams. These diagrams stand for partitioning of a plane with points into convex polygons such that each polygon (Voronoi cell) contains exactly one generating point.

The mentioned cells, otherwise also known as Thiessen polygons, are widely used in GIS modelling of archaeological and other data. The Voronoi cells in our case divided the given space (ternary diagram) using the percentage of $\mathrm{Cu}$, As and $\mathrm{Sn}$ in our metal pellets (see Table 1) as unique descriptors for XYZ positions. Each cell includes all points that are closer to its generating point than to any other in the observed space. This implies that the 'borders' of these cells are drawn at equidistance between two generating points connected with a direct line. Hence, these borders will divide the data limits until there are no more generating points to take into account. The number and shape of the Voronoi cells are determined by the sample feeds - and no data will ever exist outside the diagram (viable range for values is $0 \%-100 \%$ of presence within the given Cu-As-Sn alloy).

By using the $\mathrm{XYZ}$ position of metal pellets, we created convex polygons out of line segments that are on the equidistance from the two nearest points on the plane. In other words, the space contained within a single Voronoi cell belongs to a corresponding descriptor (or chemical composition), and it is spatially closer to that descriptor than to any other. Fig. 3 represents the full Cu-As-Sn colour diagram divided into 71 Voronoi cells with the background made of sampled images of metal alloys (or textures). In Fig. 4 we see the Cu corner ( $100 \mathrm{wt} \% \mathrm{Cu}-30 \mathrm{wt} \%$ As - $30 \mathrm{wt} \% \mathrm{Sn}$ ) with the same texturized background, however, with more clarity in the distribution of Voronoi cells within the compositional region of archaeometallurgical interest.

For the final outcome, the Voronoi cells were filled with either textures or RGB colorimetric values (Figs. 5e8). The texturized segments provided a graphic representation that remained true to the originally photographed pellets (Figs. 5 and 6), while the colorimetric values are presented in Figs. 7 and 8 . The original textures are also presented individually in Fig. 9, with the corresponding numerical and compositional values for each sample. In an additional figure (Fig. 10) we show the enhanced version of Fig. 8 with a 50\% increase in saturation, which was added in the image editor (Photoshop CS6) to bring out the intensity of its colours. We opted for this particular image as it represents the corner of the $\mathrm{Cu}$ As-Sn diagram that is of greatest interest for archaeometallurgists. When using this image, it should therefore be borne in mind that the intensity of colours was enhanced artificially; similarly artificial colours are commonly used in the $\mathrm{Cu}-\mathrm{Ag}$-Au diagram to emphasise differences between colour regions.

Before we address the peculiarities of each approach to building the diagrams, it is important to emphasise here that the Voronoi cells represent mathematically calculated 'spaces' filled with col- ours (textures or RGB colorimetric values) that become larger when there are 'missing values' in the system. We underline this information since our experimental study did not exhaust all potential options for combinations of three metal elements ( $\mathrm{Cu}, \mathrm{As}, \mathrm{Sn})$ in their binary and ternary systems, but used only the gained com-positions reported in Table 1 . While there is reasonably good coverage for the Cu corner (100 
wt\% $\mathrm{Cu}-30 \mathrm{wt} \%$ As - $30 \mathrm{wt} \% \mathrm{Sn}$ ), as the most relevant for archaeometallurgical studies, there are a few gaps on the Cu-As axis that likely result in unrealistically dramatic colour changes, most apparently with the cells 62,63 and 64 on the Cu-As axis between 6 wt\% and 11 wt\% of As content (Fig. 4, Table 1). Owing to difficulties (e.g. volatility of As) involved in producing projected values of arsenic in Cu-As alloys, such as $6 \mathrm{wt} \%, 8 \mathrm{wt} \%$ and $10 \%$, the only values that fed into our ternary colour model for the Cu-As axis between $6 \mathrm{wt} \%$ and $11 \mathrm{wt} \%$ of As content are those between $4.3 \mathrm{wt} \%$ and $6.2 \mathrm{wt} \%$, and the diagram may to be gradual as the compositions change. In future work we will explore alternative approaches to plotting colours, ideally highlighting boundaries only in those regions where they do exist.

If we turn to a comparison between the diagrams produced by the two approaches (textures vs colorimetric RGB), general differences are apparent, most notably in that the colorimetry-based ternary diagrams (Figs. 7 and 8) show warmer, redder colours. This may derive from our need to reduce specular reflection in the photographic data collection, as mentioned above. We should also bear in mind that the surface finish was not the same for both data acquisition campaigns (1200 grit for textures, 4000 for colorimetry). The qualitative comparison allows us to address cases where the colour of a particular cell stands out exceptionally among those surrounding it. In some cases there is no agreement between both diagrams (e.g. cells 11 and 40 appear darker in the texture diagram in Fig. 4 but better blended with the surrounding ones in the colorimetry-based ternary diagram in Fig. 8). Most likely, this is caused by difficulties in selecting reproducible textures from the photographs, and perhaps variability in the orientation of grinding marks on the photographs. A cursory comparison between the RGB values of textures (extracted in Table S2) and those of colorimetry (Table 5 ) is presented here in the mirror scatterplot of $G$ vs $B$ and $G$ vs $R$ in Fig. 11. It is interesting to note that the texture data are more strongly correlated than the colorimetric values. Texture $G$ values show a wider spread than colorimetry, and colorimetry shows generally higher $\mathrm{R}$ and lower $\mathrm{B}$ values. These disparities might again be a result of differences in final surface polish, or the lower sensitivity to colour differences of camera settings as opposed to colorimeter. We will explore this matter in further publications coming out of this research.

\subsection{A case study}

As an initial illustration of the use of the ternary colour diagrams produced in this way, we used the composition of the earliest known tin bronze artefacts as a case study to investigate the colour of these items at the time of production. Fifteen artefacts, very likely used for decorative purposes, were discovered throughout the Balkans and dated between the mid and late $5^{\text {th }}$ millennium BC (Radivojević et al., 2013). The authors (Radivojević et al., 2013: 1040) claimed that the golden hue of artefacts containing between c. $1 \mathrm{wt} \%$ to c. $12 \mathrm{wt} \%$ Sn must have been decisive for their appeal, particularly as these artefacts were roughly contemporary with the emergence of the earliest known gold artefacts, unearthed in the cemeteries of Varna and Durankulak in Bulgaria (cf. Todorova and Vajsov, 2001; Avramova, 2002; Dimitrov, 2002; Higham et al., 2007; Leusch et al., 2014). These fifteen items were divided in three compositional groups: stannite, high-tin fahlore and low-tin fahlore (Radivojević et al., 2013: 1035, Table 1), based on the presumed type of copper-tin bearing ore included in the charge for their making. Fig. 12 indicates that the stannite and high-tin fahlore group (12 artefacts, Sn range between $6 \mathrm{wt} \%$ and $12 \mathrm{wt} \%$ ) indeed had a visibly emphasised golden hue when produced, as opposed to the low-tin fahlore group, where colour change would have been noticeable, however, not as significant as for those above c. $5 \mathrm{wt} \%$.

We therefore conclude that the group of Balkan tin bronze artefacts, in particular the assemblage of stannite and high-tin fahlore group, must have aesthetically appeared significantly different from pure 
copper artefacts, since the addition of tin increased the golden hue of their resultant colour. With such a different appearance, it is very likely that the production of the $5^{\text {th }}$ millennium BC Balkan tin bronzes had been dictated by the demand for the 'exotic' golden colour at the time, or by the pursuit of its closest imitation, which overall supports the propositions made in the original publication (Radivojević et al., 2013; see also Radivojević et al., 2014).

\section{Conclusion}

The projected and gained values in Tables 1 and 4 show that the greatest losses in the experimental making phase of our research occurred with arsenic. This was not unexpected, since arsenic is known as volatile, particularly in oxidising conditions (e.g. McKerrell and Tylecote, 1972; Sabatini, 2015). Also, the differences in projected and gained values of all three elements projections might have occurred due to structure defects (e.g. porosity, grain size, or other casting defects), or probably during solidification. We will address these matters in more detail in the sequel to this study.

To the best of our knowledge, this work represents the most exhaustive investigation of the colour of $\mathrm{Cu}$ As-Sn alloys to date. The results presented in Figs. 7-9 are in good agreement with the results of previous studies on colour change in tin bronzes (cf. Магницкий and Пирайнен, 1996: 65, Tab. 2.19; Fang and McDonnell, 2011) but allow a visual representation: a noticeable change from copper red to pale pink occurs after the addition of up to c. $5 \mathrm{wt} \% \mathrm{Sn}$, after which the yellow hue increases and dominates this alloy up to the mark of $20 \mathrm{wt} \% \mathrm{Sn}$. Past this mark the yellow hue decreases and reaches silvery appearance around $30 \mathrm{wt} \%$. For the arsenic additions the situation is slightly different: the colour of Cu- As alloys up to c. $11 \mathrm{wt} \%$ changes from copper red to pale pink, although we are unable to tell what happens between $6 \mathrm{wt} \%$ and 11 wt\% (Figs. 4, 6 and 8, see also above). The colour of $\mathrm{Cu}$-As alloys past this point turns into silver (Figs. 5 and 7). The ternary Cu-As-Sn alloys are largely yellow in appearance; alloying with Sn reduces the redness again and enhances the yellow hue of alloys. Yet, after the $5 \mathrm{wt} \%$ As point in ternary Cu-AsSn alloys, the decrease in both yellow and red hue is noticeable, driving the ternary alloys with more than $5 \mathrm{wt} \%$ of As in the said system into a silvery colour.

Overall, the silver hue dominates the ternary $\mathrm{Cu}$-As-Sn colour diagram, with the only exception being the Cu corner with up to $30 \mathrm{wt} \%$ of As and Sn (Figs. 6, 8 and 10). This corner, however, is the most important for investigating the aesthetics of prehistoric cop-per alloys, as metal artefacts from the Copper and Bronze Age, for instance, would usually cluster around the mentioned values. Further validation of the Cu-As-Sn ternary colour diagrams was provided by plotting the chemical composition of the $5^{\text {th }}$ millennium BC Balkan tin bronzes, which are presented as artefacts with noticeable increased golden and reduced red hue, particularly above c. 5 wt\% of Sn (Fig. 12).

Needless to say, the colours presented here are only applicable to archaeological artefacts if we have the certainty that the latter had not undergone patination, gilding or other surface treatments that would have modified their surface colour. Even in the absence of deliberate colouring treatments, aspects derived from the manufacturing technology and affecting the metal structure, such as cooling rates after casting, or heat treatments such as annealing or quenching, will no doubt have had an effect on colour. The degree of surface polish will have affected the perception on colour too. In addition, as mentioned above, the results of colorimetric analyses (and their conversion to RGB) will be affected by the data acquisition set up, with every mode having its own advantages and limitations. All of these aspects are the subject of ongoing research. 


\section{Acknowledgements}

The authors are indebted for the financial support from the Serbian Ministry of Science, the AHRC-funded project 'Rise of Metallurgy' (No. AH/J001406/1) and the D.M. McDonald Fund awarded by the McDonald Institute for Archaeological Research, University of Cambridge (to MR). Colorimetric measurements are part of C. Davey's MSc thesis conducted at the UCL Institute of Archaeology in 2017 and titled "The Colour of Magic: Quantitative Colour Assessment of Metals". Stuart Laidlaw from the UCL Institute of Archaeology Photography Lab designed the photography setup. We are grateful to S. Laidlaw, A. Franjić, M. Frachetti for their assistance in the laboratory and support that improved this paper. Moreover, we are grateful to $\mathrm{C}$. Korenberg and C. Heron from the British Museum for the loan of the colorimeter. Detailed comments from four anonymous reviewers helped us better situate our research; any remaining shortcomings are ours.

\section{References}

Avramova, M., 2002. Der Schmuck aus den Gräbern von Durankulak. In: Todorova, H. (Ed.), Durankulak, Band II - Die prähistorischen Gräberfelder von Durankulak, Teil 1. Publishing House Anubis Ltd. Sofia, Berlin-Sofia, pp. 191-206.

Berger, D., 2012. Bronzezeitliche Färbetechniken an Metallobjekten nördlich der Alpen: Eine archäometallurgische Studie zur prähistorischen Anwendung von Tauschierung und Patinierung anhand von Artefakten und Experimenten. Landesmuseum für Vorgeschichte Halle, Halle/Saale.

Berger, D., Schwab, R., Wunderlich, C.-H., 2010. Technologische Untersuchungen zu bronzezeitlichen Metallziertechniken nördlich der Alpen vor dem Hintergrund des Hortfundes von Nebra. In: Meller, H., Bertemes, F. (Eds.), Der Griff nach den Sternen: Wie Europas Eliten zu Macht und Reichtum kamen. Internationales Symposium in Halle (Saale), 16.-21. Februar 2005. Landesmuseum für Vorgeschichte Halle, Halle/Saale, pp. 751-778.

Bochvar, N.R., Materials Science International Team, 1994. As-Cu-Sn ternary phase diagram evaluation. Phase diagrams, crystallographic and thermodynamic data: datasheet from MSI Eureka in SpringerMaterials. In: Effenberg, G. (Ed.), MSI Eureka in SpringerMaterials. MSI Materials Science International Services GmbH, Stuttgart. http://materials.springer.com/msi/docs/sm_msi_r_10_ 016574_01.

Bourgarit, D., 2003. La couleur des alliages anciens à base de cuivre. In: École thématique interdisciplinaire sur la couleur des matériaux. École thématique interdisciplinaire sur la couleur des matériaux, le métal. Du 17 mars au 21 mars, École de printemps 2003, Roussillon. Conservatoire des ocres et pigments appliqués, Roussillon, pp. 1-18.

Budd, P., 1991. Eneolithic arsenical copper - heat-treatment and the metallographic interpretation of manufacturing processes. In: Pernicka, E., Wagner, G.A. (Eds.), Archaeometry '90: International Symposium in Archaeometry. Birkhäuser Verlag, Heidelberg, pp. 35-44.

Chapman, J., 2007. The elaboration of an aesthetic of brilliance and colour in the climax Copper Age. In: Lang, F., Reinholdt, C., Weilhartner, J. (Eds.), Stephanos Aristeios. Archäologische Forschungen zwischen Nil und Istros. Festschrift für Stefan Hiller zum 65. Geburtstag. Phoibos Verlag, Wien, pp. 6574. 
Chase, W.T., 1994. Chinese bronzes: casting, finishing, patination, and corrosion. In: Scott, D.A., Podany, J., Considine, B.B. (Eds.), Ancient and Historic Metals: Conservation and Scientific Research. Proceedings of a Symposium on Ancient and Historic Metals Organized by the J. Paul Getty Museum and the Getty Conservation Institute, November 1991. Getty Conservation Institute, Marina del Rey, CA, pp. 85-117.

Cretu, C., van der Lingen, E., 1999. Coloured gold alloys. Gold Bull. 32, 115-126.

Dimitrov, K., 2002. Die Metallfunde aus den Gräberfeldern von Durankulak. In: Todorova, H. (Ed.), Durankulak, Band II - Die prähistorischen Gräberfelder von Durankulak, Teil 1. Publishing House Anubis, Berlin-Sofia, pp. 127-158.

Fang, J.L., McDonnell, G., 2011. The colour of copper alloys. Hist. Metall. 45, 52-61.

Gell, A., 1992. The technology of enchantment and the enchantment of technology. In: Coote, J., Shelton, A. (Eds.), Anthropology, Art and Aesthetics. Clarendon, Oxford, pp. 40-67.

German, R.M., 1982. Precious-metal dental casting alloys. Int. Met. Rev. 27, 260-288.

German, R.M., Guzowski, M.M., Wright, D.C., 1980. The colour of gold-silver-copper alloys. Gold Bull. 13, 113-116.

Higham, T., Chapman, J., Gaydarska, B., Slavchev, V., Honch, N., Yordanov, Y., Dimitrova, B., 2007. New perspectives on the Varna cemetery (Bulgaria) - AMS dates and social implications. Antiquity 81, 640654.

Hosler, D., 1994. The Sounds and Colors of Power: the Sacred Metallurgical Technology of Ancient West Mexico. The MIT Press, Cambridge, MA.

Hunter, R.S., Harold, R.W., 1987. The Measurement of Appearance. John Wiley \& Sons, New York.

Jones, A., 2004. Archaeometry and materiality: materials-based analysis in theory and practice. Archaeometry 46, 327-338.

Jones, A., MacGregor, G. (Eds.), 2002. Colouring the Past. The Significance of Colour in Archaeological Research. Berg, Oxford.

Killick, D., Fenn, T.R., 2012. Archaeometallurgy: the study of preindustrial mining and metallurgy. Annu. Rev. Anthropol. 41, 559-575.

Lechtman, H., 1977. Style in technology-some early thoughts. In: Lechtman, H., Merrill, R.S. (Eds.), Material Culture: Styles, Organization and Dynamics in Technology. West Publishing, St. Paul, pp. 3-20.

Lechtman, H., 1980. The Central Andes: metallurgy without iron. In: Wertime, T.A., Muhly, J.D. (Eds.), The Coming of the Age of Iron. Yale University Press, New Haven, London, pp. 267-334.

Lechtman, H., 1996. Arsenic bronze: dirty copper or chosen alloy? A view from the Americas. J. Field Archaeol. 23, 477-514.

Leusch, V., Pernicka, E., Armbruster, B., 2014. Chalcolithic gold from Varna - provenance, circulation, processing, and function. In: Meller, H., Risch, R., Pernicka, E. (Eds.), Metals of Power-early Gold and 
Silver. $6^{\text {th }}$ Archaeological Conference of Central Germany, October 17-19, 2013, Halle. Landesamt für Denkmalpflege und Archäologie Sachsen-Anhalt/Landesmuseum für Vorgeschichte, Halle, pp. 165182.

Leusch, V., Armbruster, B., Pernicka, E., Slavčev, V., 2015. On the invention of gold metallurgy: the gold objects from the Varna I cemetery (Bulgaria) - technological consequence and inventive creativity. Camb. Archaeol. J. 25, 353-376.

Leuser, J., 1949. Über die Besonderheiten der Edelmetallegierungen im Schmuckgewerbe. Metall 3, 105110.

Martinón-Torres, M., Rehren, Th, 2009. Post-medieval crucible production and distribution: a study of materials and materialities. Archaeometry 51, 49-74.

Martinón-Torres, M., Uribe-Villegas, M.A., 2015a. The prehistoric individual, connoisseurship and archaeological science: the Muisca goldwork of Colombia. J. Archaeol. Sci. 63, 136-155.

Martinón-Torres, M., Uribe-Villegas, M.A., 2015b. Technology and culture in the invention of lost-wax casting in South America: an archaeometric and ethno- archaeological perspective. Camb. Archaeol. J. 25, 377-390.

Martinón-Torres, M., Rojas, R.V., Cooper, J., Rehren, Th, 2007. Metals, microanalysis and meaning: a study of metal objects excavated from the indigenous cemetery of El Chorro de Maíta, Cuba. J. Archaeol. Sci. 34, 194-204.

McDonald, A.S., Sistare, G.H., 1978. The metallurgy of some carat gold jewellery alloys. Gold Bull. 11, 6673.

McKerrell, H., Tylecote, R.F., 1972. The working of copper-arsenic alloys in the Early Bronze Age and the effect on the determination of provenance. Proc. Prehist. Soc. 38, 209-218.

Meeks, N.D., 1986. Tin-rich surfaces on bronze - some experimental and archaeological considerations. Archaeometry 28, 133-162.

Meeks, N., 1993. Surface characterization of tinned bronze, high-tin bronze, tinned iron and arsenical bronze. In: La Niece, S., Craddock, P.T. (Eds.), Metal Plating and Patination: Cultural, Technical and Historical Developments. Butterworth- Heinemann, Oxford, pp. 247-275.

Mödlinger, M., Sabatini, B., 2016. A Re-evaluation of inverse segregation in pre-historic As-Cu objects. J. Archaeol. Sci. 74, 60-74.

Mödlinger, M., Kuijpers, M., Braekmans, D., Berger, D., 2017. Quantitative comparisons of the color of CuAs, CuSn, CuNi, and CuSb alloys. J. Archaeol. Sci. 88, 14-23.

Needham, J., 1962. Science and Civilisation in China, IV:1. Cambridge University Press, Cambridge.

Northover, J.P., 1989. Properties and use of arsenic-copper alloys. In: Hauptmann, A., Pernicka, E., Wagner, G.A. (Eds.), Old World Archaeometallurgy. Deutsches Bergbau-Museum, Bochum, pp. 111118. 
Radivojević, M., 2015. Inventing metallurgy in western Eurasia: a look through the microscope lens. Camb. Archaeol. J. 25, 321-338.

Radivojević, M., Rehren, Th, 2016. Paint it black: the rise of metallurgy in the Bal- kans. J. Archaeol. Method Theory 23, 200-237.

Radivojević, M., Rehren, Th., Kuzmanović-Cvetković, J., Jovanović, M., Northover, J.P., 2013. Tainted ores and the rise of tin bronze metallurgy, c. 6500 years ago. Antiquity 87, 1030-1045.

Radivojević, M., Rehren, Th., Kuzmanović-Cvetković, J., Jovanović, M., 2014. Context is everything indeed: a response to Šljivar and Borić. Antiquity 88, 1315-1319.

Rapson, W.S., 1990. The metallurgy of the coloured carat gold alloys. Gold Bull. 23, 125-133.

Roberts, E.F.I., Clarke, K.M., 1979. The colour characteristics of gold alloys. Gold Bull. 12, 9-19.

Roeder, J.F., Notis, M.R., 1985. Electron microprobe determination of phase equilibria in the Cu-As-Sn system. In: Armstrong, J.T. (Ed.), Microbeam Analysis 1985: Proceedings of the $20^{\text {th }}$ Annual Conference of the Microbeam Analysis Society, Louisville, Kentucky, 5-9 August 1985. San Francisco Press, San Francisco, pp. 170-172.

Roeder, J.F., Notis, M.R., 1987. Phase equilibria in the Cu-Rich corner of the Cu-As-Sn system. Z. Met. 78, 802-809.

Roeder, J.F., Notis, M.R., Tarby, S.K., 1986. CAD representation of phase diagrams and experimental phase equilibria determination the Cu-As-Sn system. In: Bennett, L.H. (Ed.), Computer Modeling of Phase Diagrams: Proceedings of a Symposium Sponsored by the Alloy Phase Diagram Data Committee of the Materials Science Division of the American Society for Metals, Held at the Fall Meeting of the Metallurgical Society in Toronto, Canada, October 13-17, 1985. American Society for Metals, Alloy Phase Diagram Data Committee, Warrendale, Pa, pp. 385-398.

Sabatini, B., 2015. The As-Cu-Ni system: a chemical thermodynamic model for ancient recycling. J. Metals 67, 2984-2992.

Sáenz-Samper, J., Martinón-Torres, M., 2017. Depletion gilding, innovation and life-histories: the changing colours of Nahuange metalwork (Colombia). Antiquity 91, 1254-1267.

Saunders, N.J., 2011. To capture the sun: gold of ancient Panama. In: Hoopes, J.W., Quilter, J., Saunders, N.J., Cooke, R.G. (Eds.), Shimmering Worlds: Brilliance, Power, and Gold in Pre-Columbian Panama. Gilcrease Museum and University of Oklahoma Press, Tulsa, Okla, pp. 78-113.

Shah, H.S., Gandhi, R.S., 1990. Instrumental Colour Measurements and Computer Aided Colour Matching for Textiles. Mahajan Book Publishers, Ahmedabad.

Smith, C.S., 1975. Metallurgy as a human experience. Metall. Trans. A 6, 603.

Smith, C.S., 1981. On art, invention and technology. In: Smith, C.S. (Ed.), A Search for Structure. The MIT Press, Cambridge (MA), pp. 325-331. 
Srejić, D., 2015. Sinteza i karakterizacija arheometalurških sastava Cu-Sn-As bronzi (Synthesis and Characterisation of Archaeometallurgical Cu-Sn-As Bronzes, in Serbian). Unpublished BSc thesis. Faculty of Metallurgy and Technology, University of Belgrade, Belgrade.

Stech, T., Maddin, R., 1988. Reflections on early metallurgy in southeast Asia. In: Maddin, R., Weng, Y.Q. (Eds.), The Beginning of the Use of Metals and Alloys. Papers from the Second International Conference of the Beginning of the Use of Metals and Alloys, Zhengzhou, China, 21-26 October 1986. The MIT Press, Cambridge, MA, pp. 163-174.

Thornton, C.P., 2007. Of brass and bronze in prehistoric southwest Asia. In: La Niece, S., Hook, D., Craddock, P. (Eds.), Metals and Mines: Studies in Archaeometallurgy. Archetype Publications, London, pp. 123-135.

Todorova, H., Vajsov, I., 2001. Der kupferzeitliche Schmuck Bulgariens, vol. 20. Steiner, Prähistorische Bronzefunde, Stuttgart. Band 6.

Yonehara, M., Matsui, T., Kihara, K., Isono, H., Kijima, A., Sugibayashi, T., 2004. Experimental relationships between surface roughness, glossiness and color of chromatic colored metals. Mater. Trans. 45, 10271032.

Магницкий, О.Н., Пирайнен, В.Ю., 1996. ХудоЖественное литье: Учебник для технических вузов и худоЖественно-реставрационных училищ. Политехника, Санкт-Петерсбург. 


\section{Appendix A. Supplementary data}

Supplementary data related to this article can be found at https://doi.org/10.17863/CAM.12524. 


\section{Appendix B. Figures}

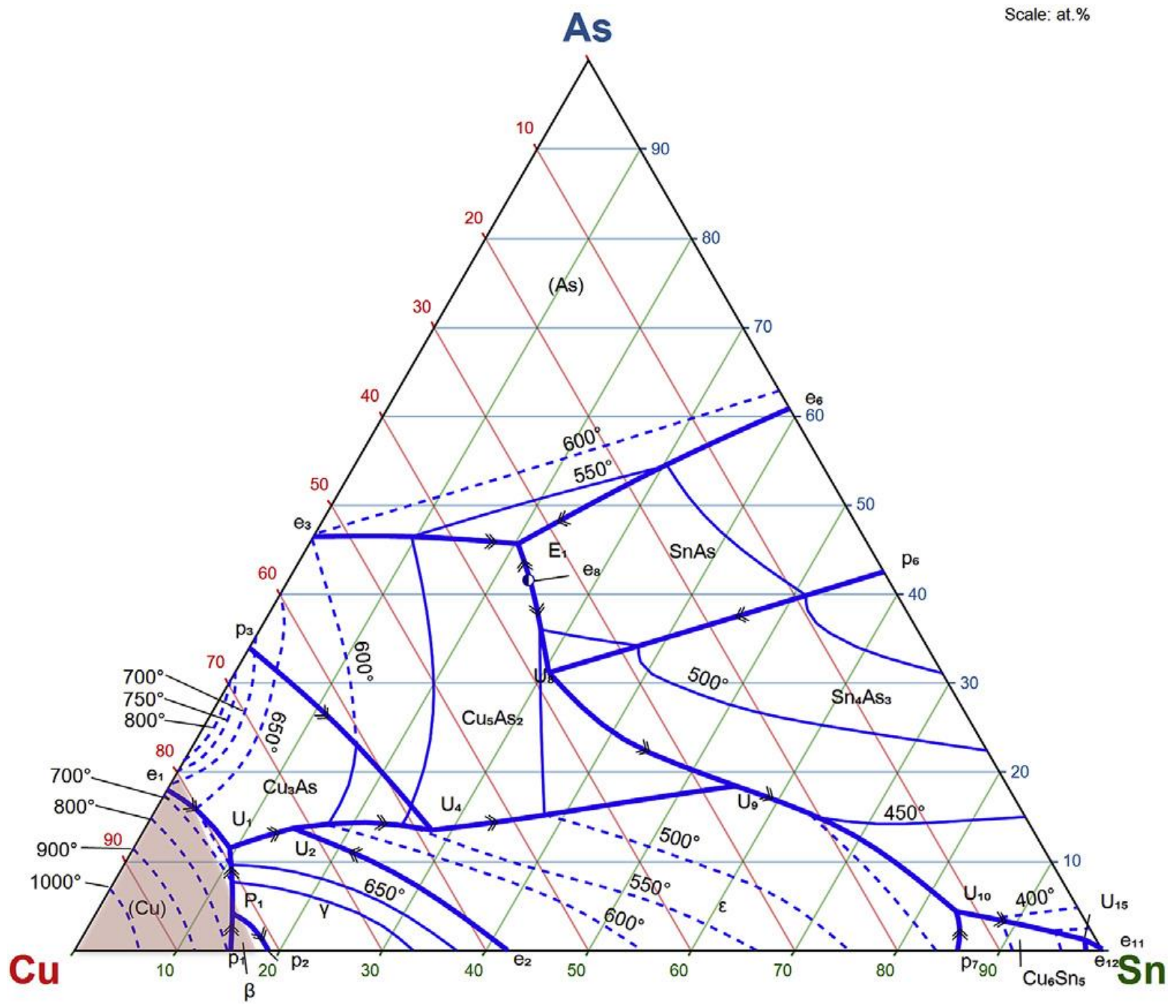

Figure 1 Fig. Cu-As-Sn ternary phase diagram. Note that in the shaded area of the Cu corner are indicated liquidus temperatures for the majority of our experimentally produced Cu-As-Sn binary and ternary alloys (compare with Fig. 3 below) (adapted after Bochvar and Materials Science International Team, 1994: Fig. 3). 


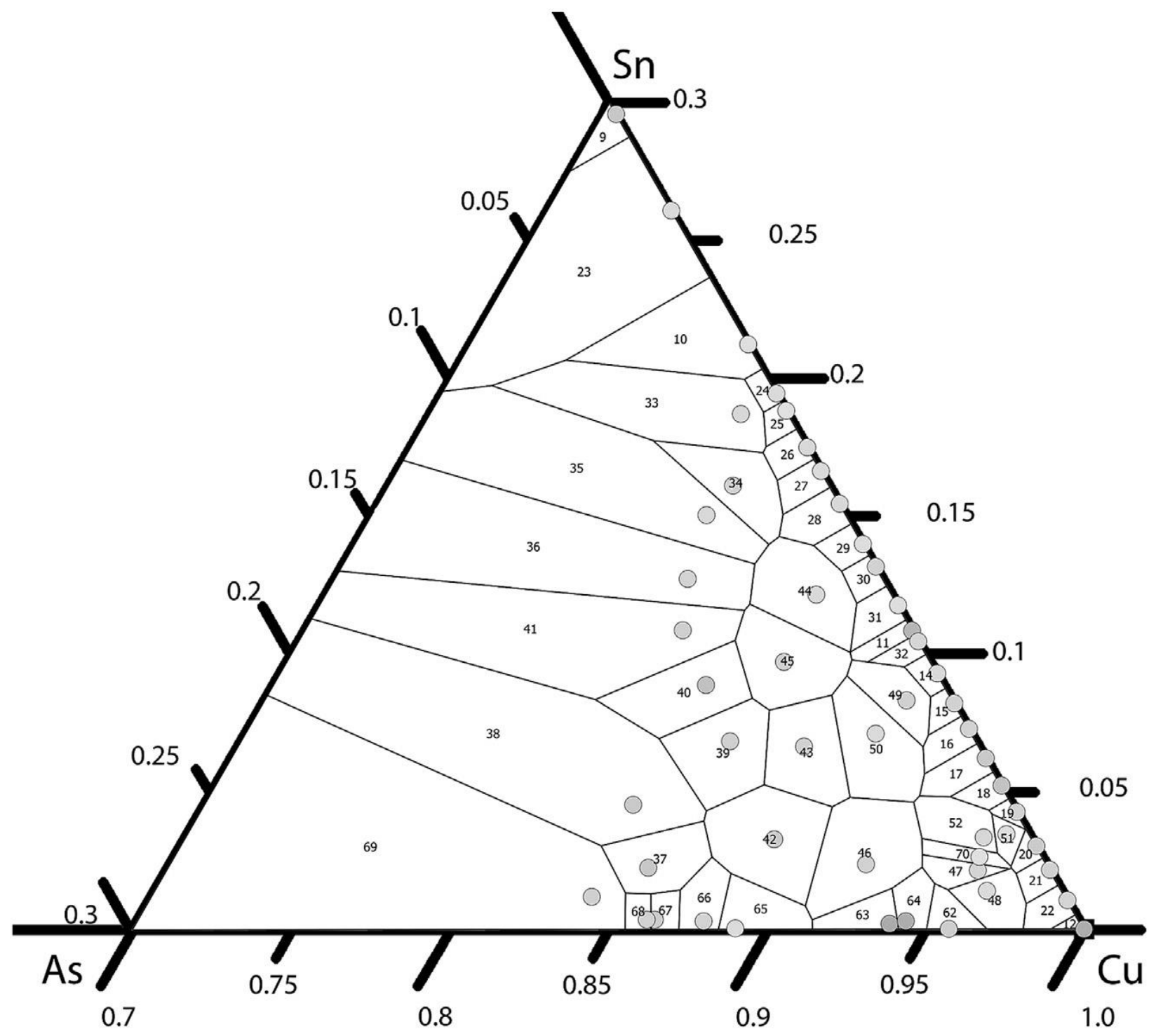

Figure 2 Ternary diagram Cu (100\%) - As (30\%) - Sn (30\%) with dots representing sampled images of binary and ternary alloys. Note corresponding alloy numbers for each dot in a designated Voronoi cell. Compare with chemical composition in Table 1. 


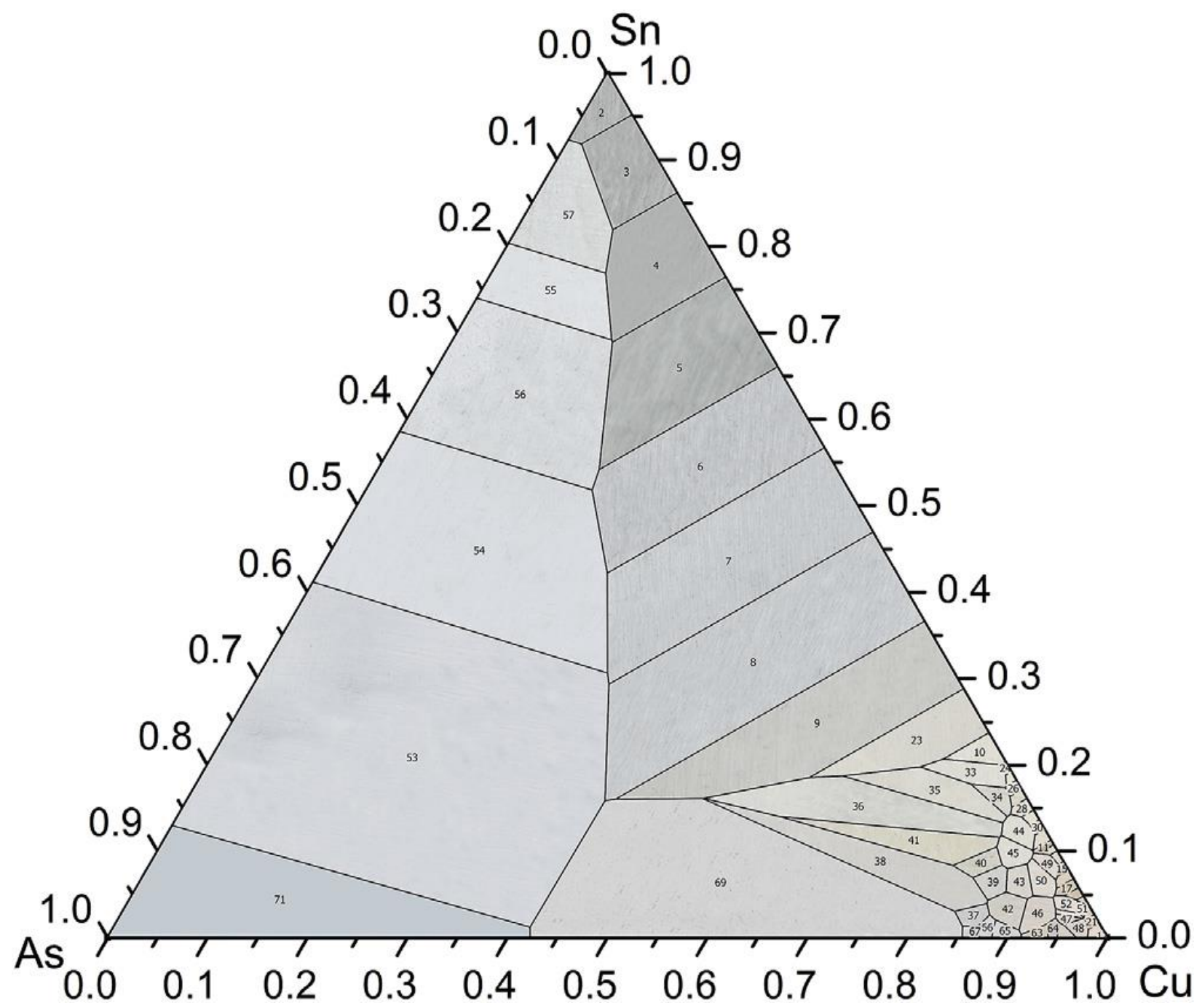

Figure 3 Ternary colour Cu-As-Sn diagram (all three elements 100\%), with 71 Voronoi cells designed as per procedure explained in the text. The background is made of samples of images of metal pellets, with each cell containing an image that corresponds to the numerical label (here: 2 to 71). (For interpretation of the references to colour in this figure legend, the reader is referred to the Web version of this article.) 


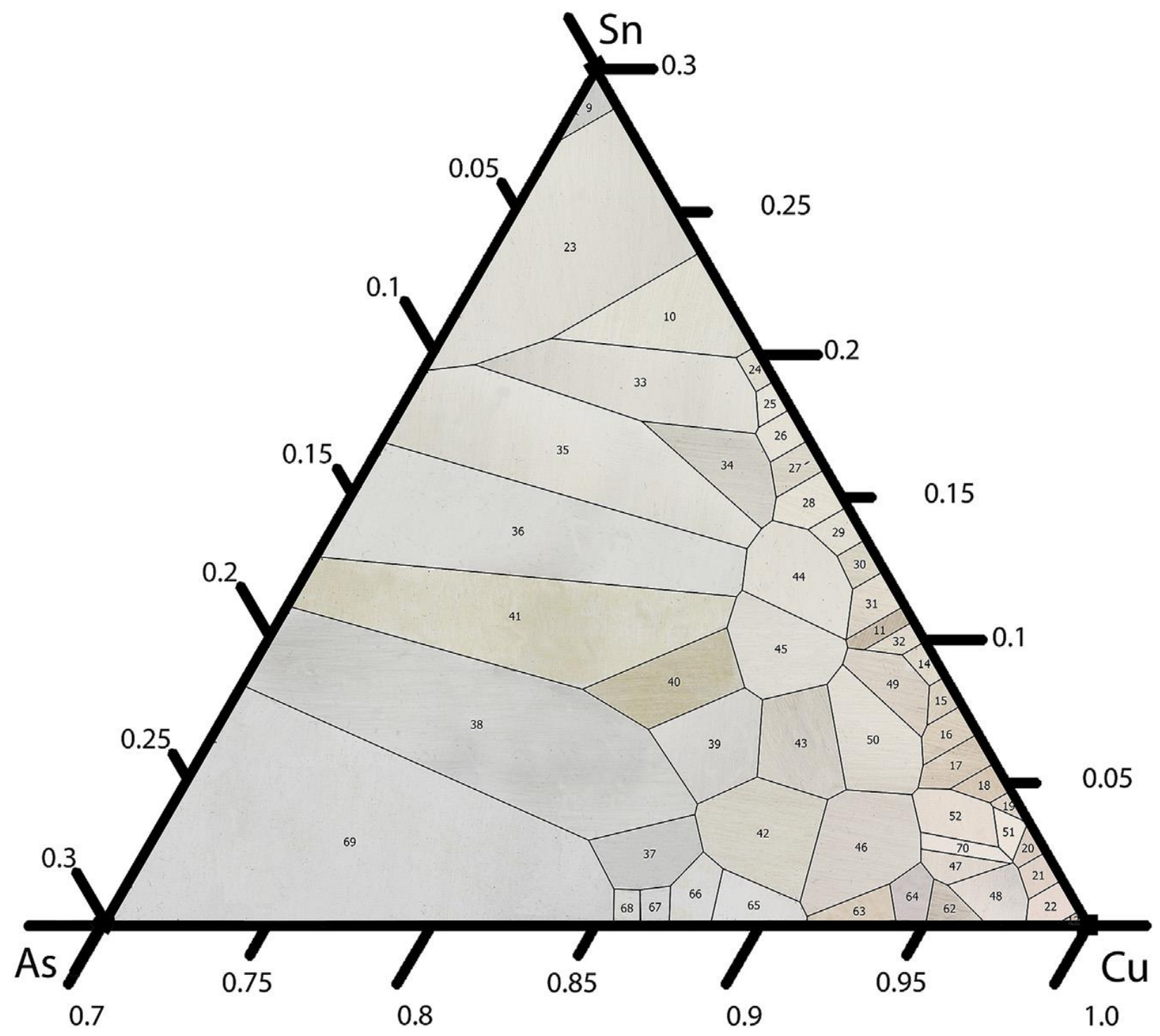

Figure 4 Ternary colour diagram (100 wt\% Cu - 30 wt\% As - 30 wt\% Sn), with numerically labelled Voronoi cells. The background is made of samples of images of metal pellets, with each cell containing an image that corresponds to the numerical label (see Table 1). (For interpretation of the references to colour in this figure legend, the reader is referred to the Web version of this article.) 


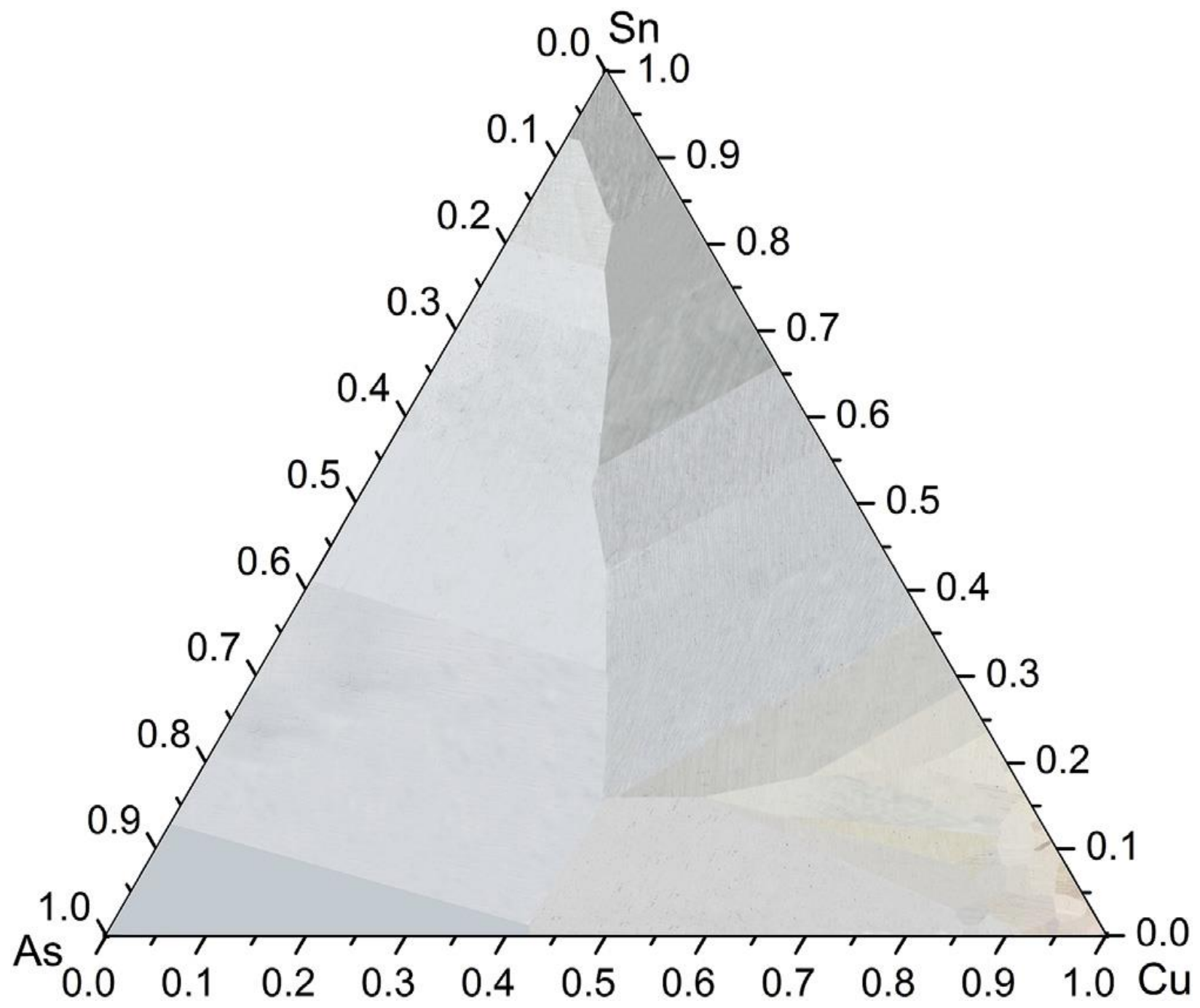

Figure 5 Ternary Cu-As-Sn (all elements 100\%) colour diagram with original textures - sampled images of experimentally produced metal pellets. Note that lines designating Voronoi cells are removed. High-resolution version available for download as Supplementary Material (Fig. S2). (For interpretation of the references to colour in this figure legend, the reader is referred to the Web version of this article.) 


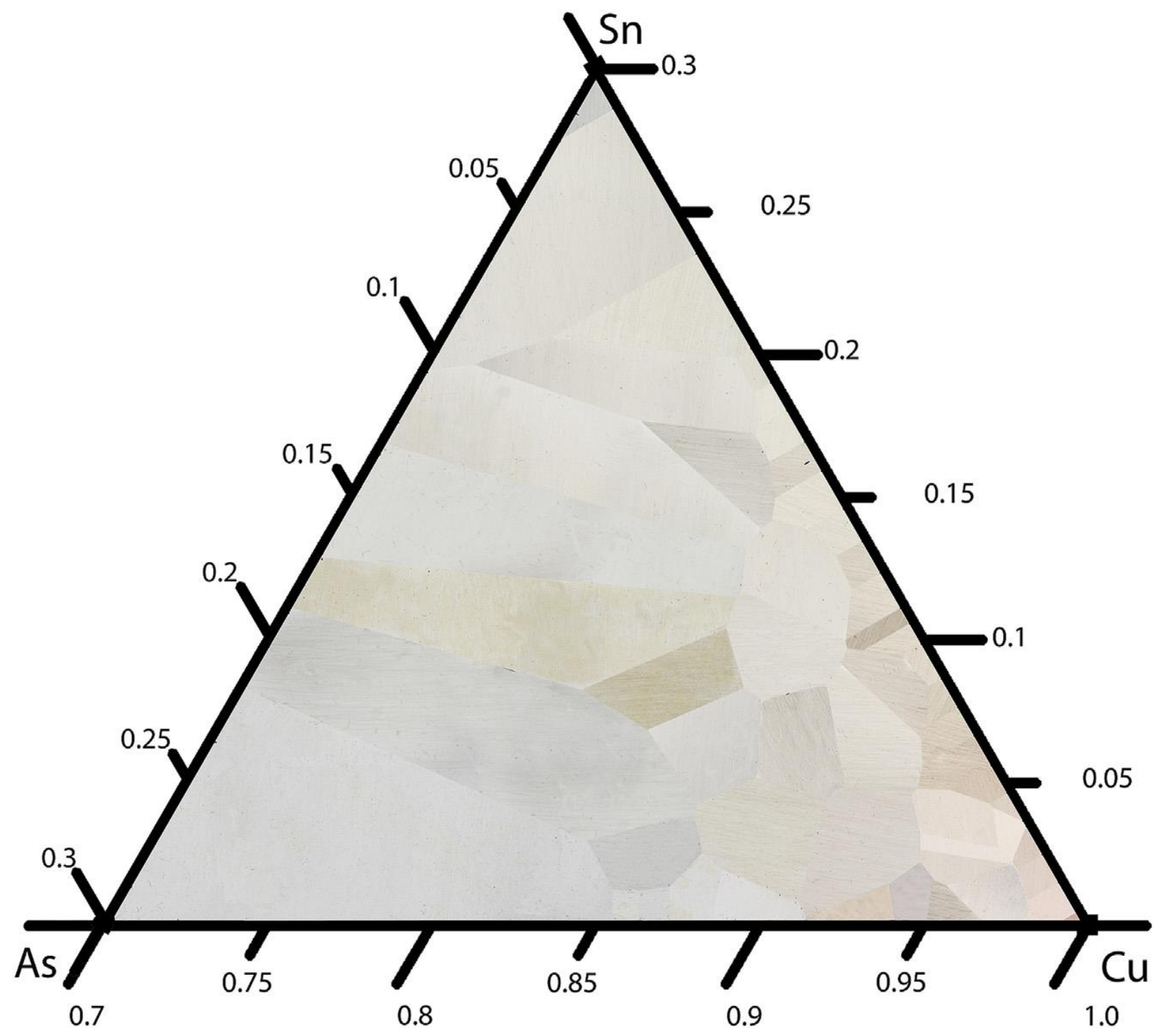

Figure 6 Ternary colour diagram (100wt\% Cu - 30 wt\% As - 30 wt\% Sn), with original textures - sampled images of experimentally produced metal pellets. High-resolution version available for download as Supplementary Material (Fig. S3). (For interpretation of the references to colour in this figure legend, the reader is referred to the Web version of this article.) 


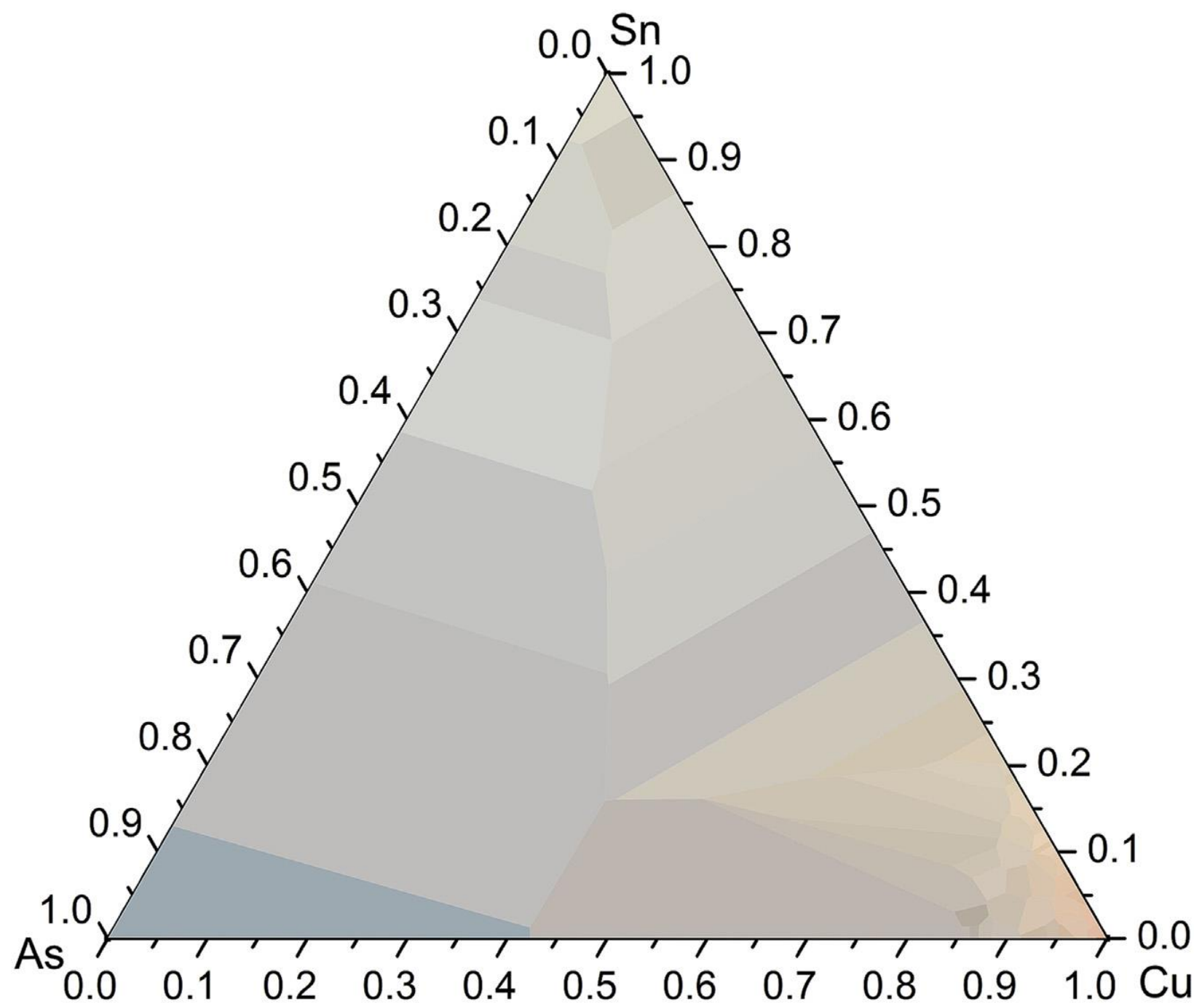

Figure 7 Ternary Cu-As-Sn (all elements 100\%) colour diagram based on colorimetric RGB values. High-resolution version available for download as Supplementary Material (Fig. S4). (For interpretation of the references to colour in this figure legend, the reader is referred to the Web version of this article.) 


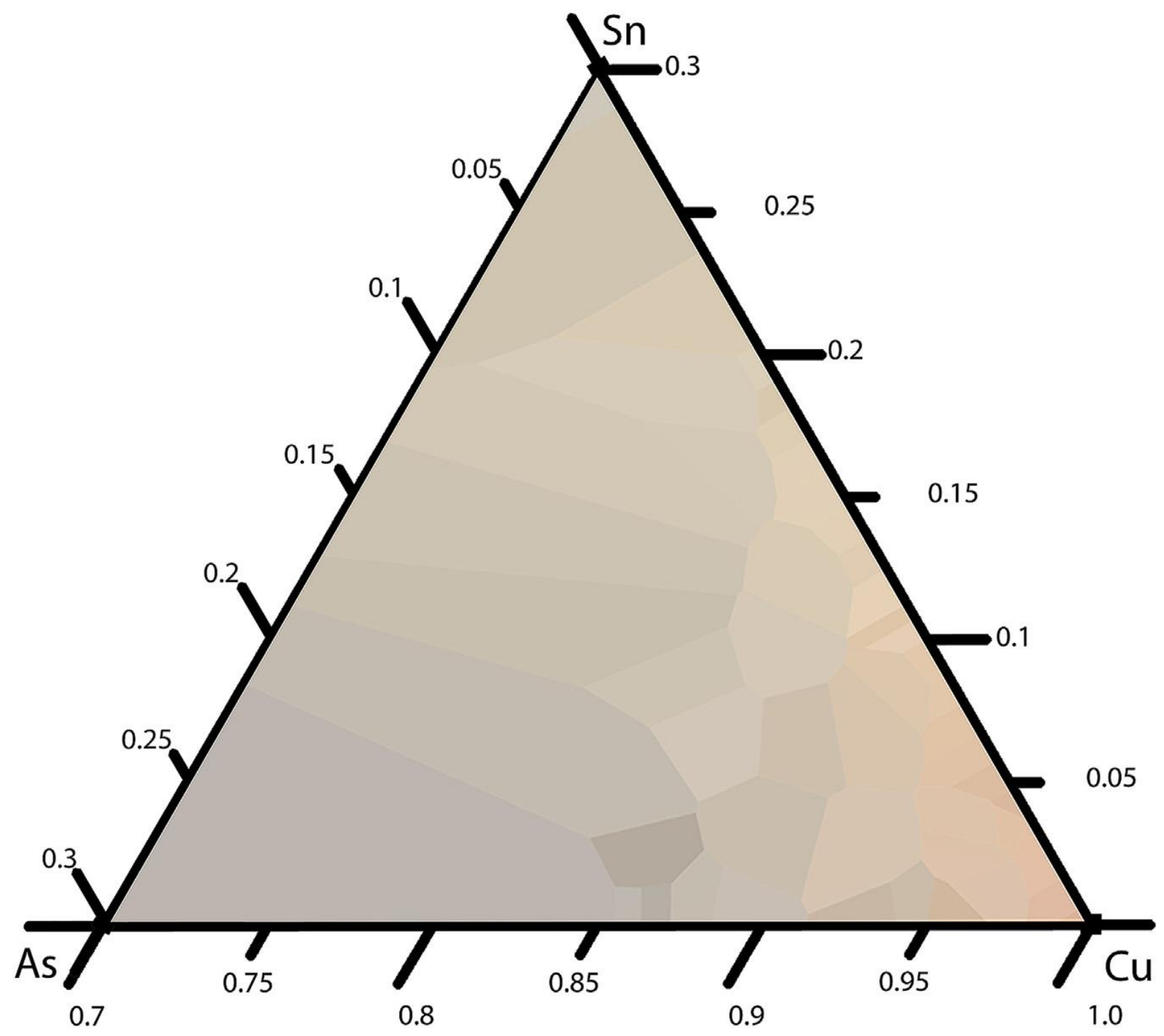

Figure 8 Ternary colour diagram (100 wt\% Cu - 30 wt\% As - 30 wt\% Sn), based on colorimetric RGB values. High-resolution version available for download as Supplementary Material (Fig. S5). (For interpretation of the references to colour in this figure legend, the reader is referred to the Web version of this article.) 


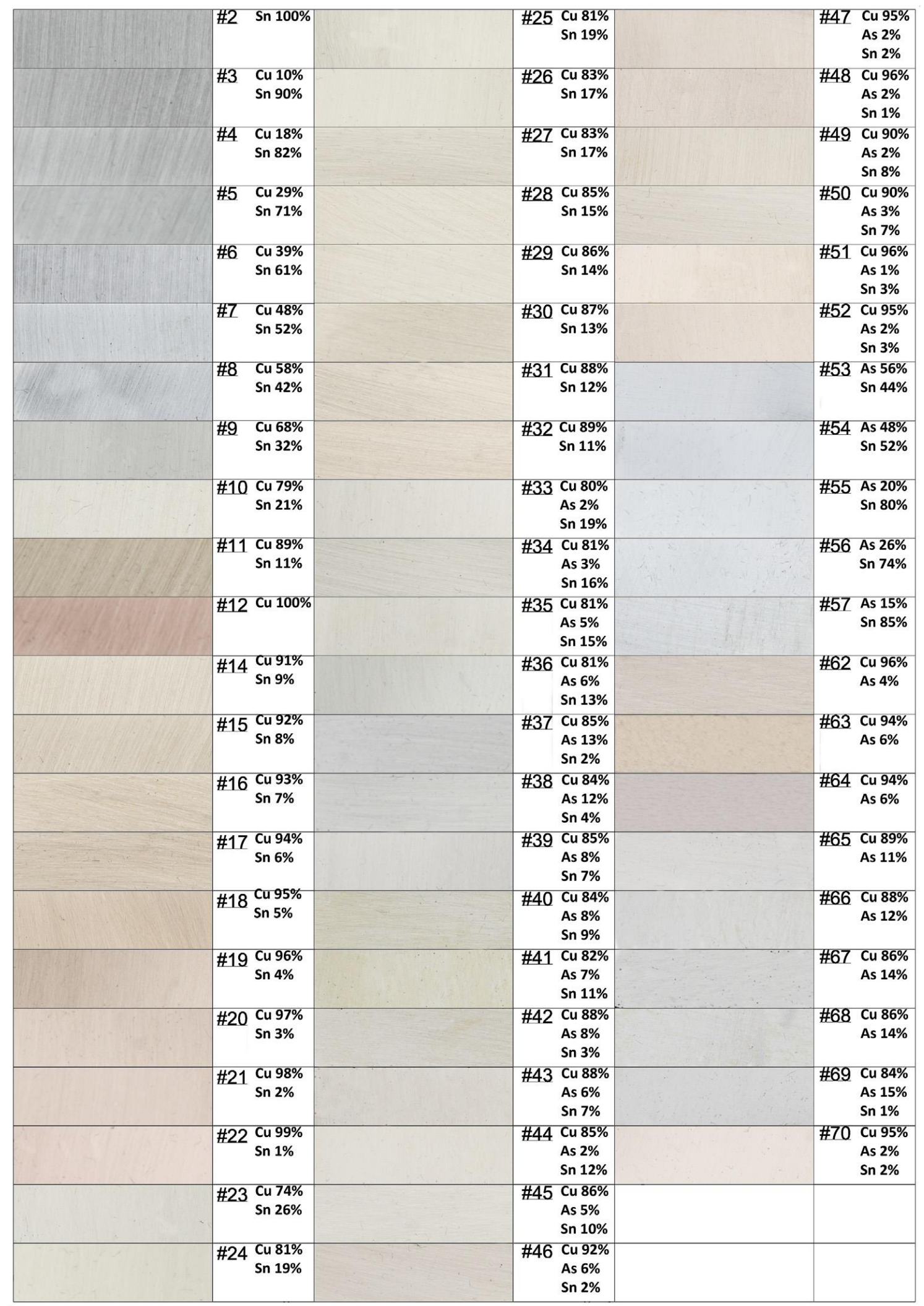

Figure 9 Sixty-four experimentally produced metal samples are presented individually, together with the numerical value of the alloy and obtained compositional reading. High resolution version available for download as Supplementary Material (Fig. S6). 


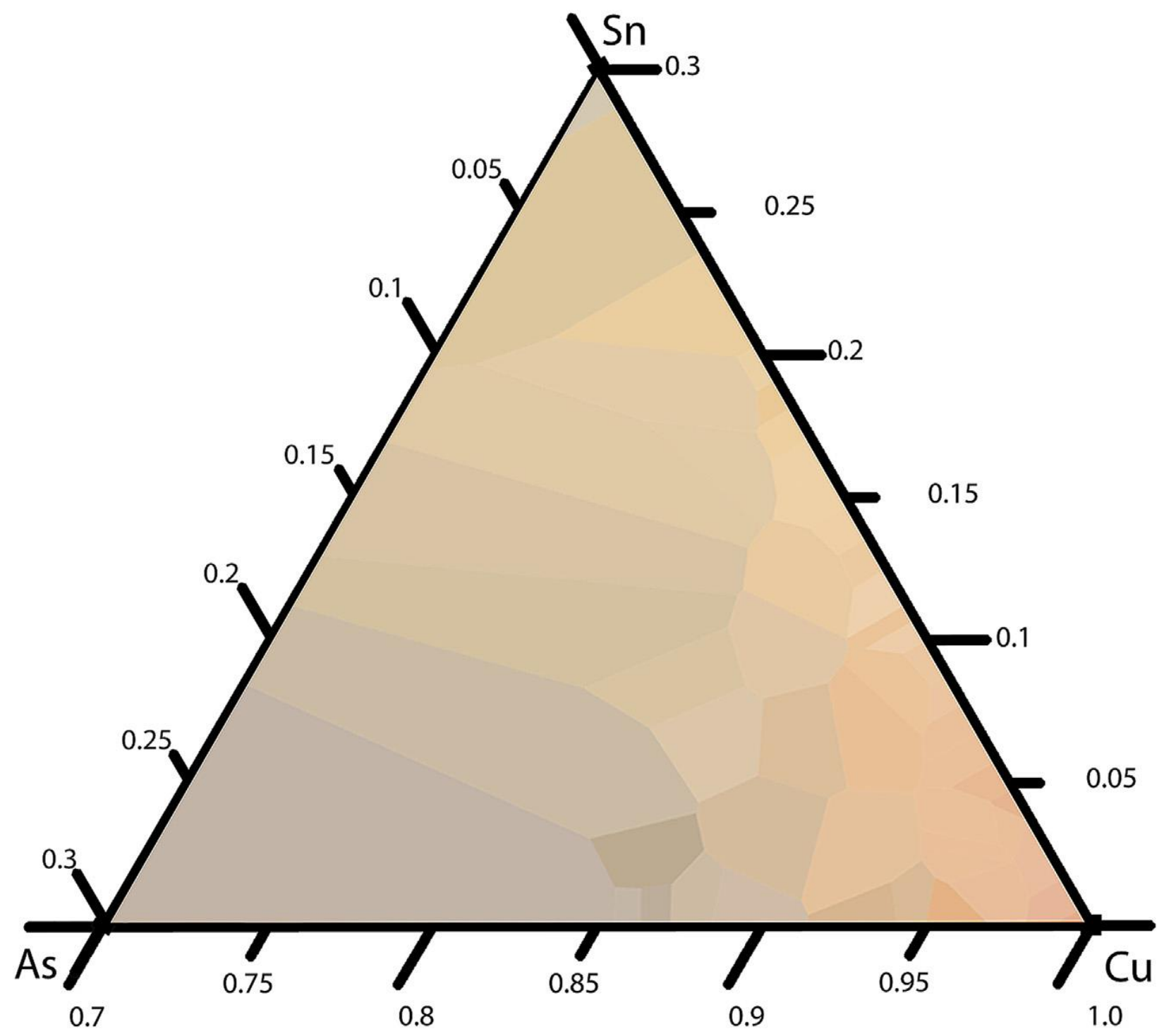

Figure 10 Ternary colour diagram (100 wt\% Cu-e 30 wt\% As - 30 wt\% Sn), based on colorimetric RGB values enhanced by $50 \%$ in intensity (saturation). High-resolution version available for download as Supplementary Material (Fig. S7). (For interpretation of the references to colour in this figure legend, the reader is referred to the Web version of this article.) 

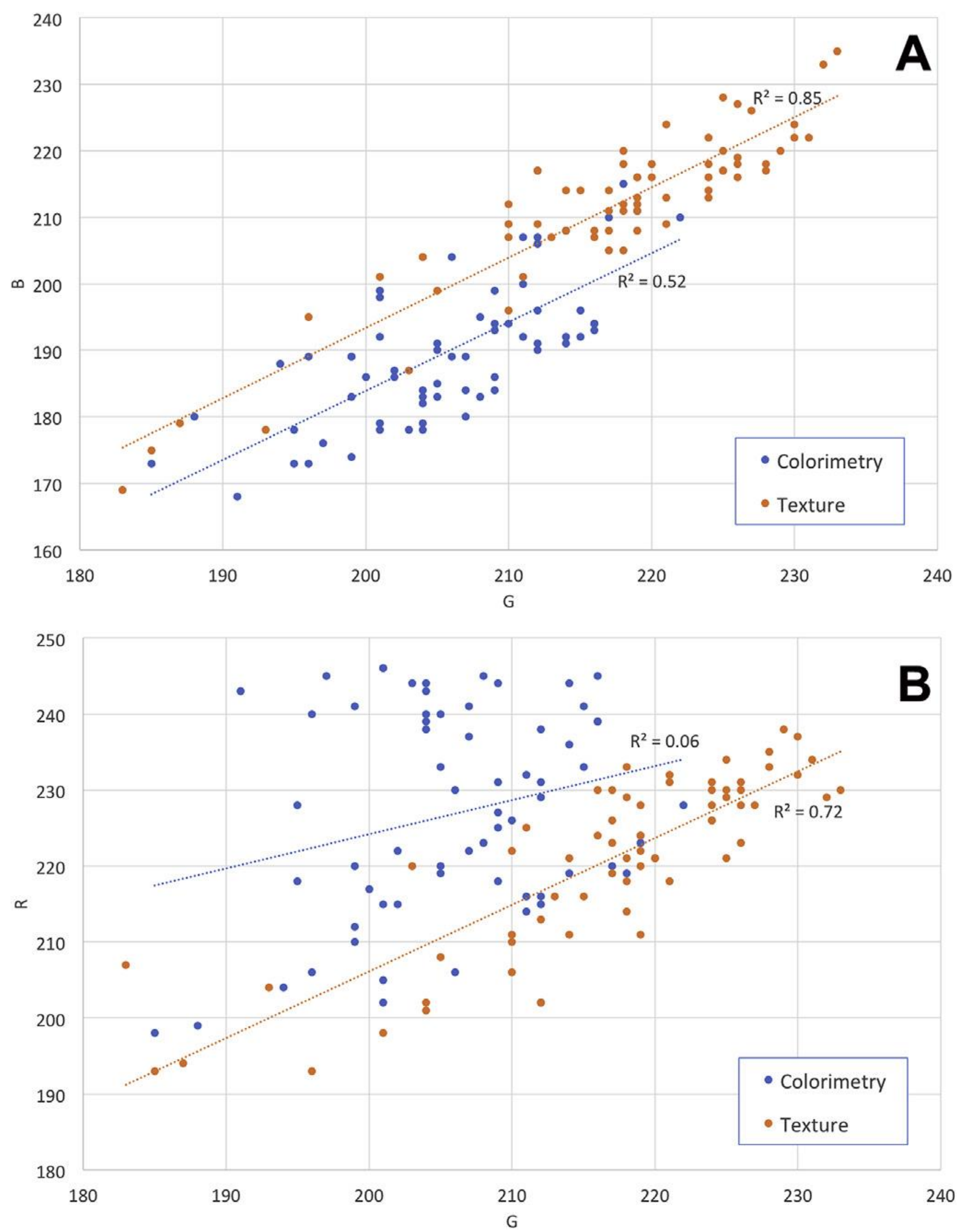

Figure 11 Double scatterplot comparing RGB values derived from photographic textures to those obtained from colorimetric measurements. See Table 5 and Table S2 for original data. 


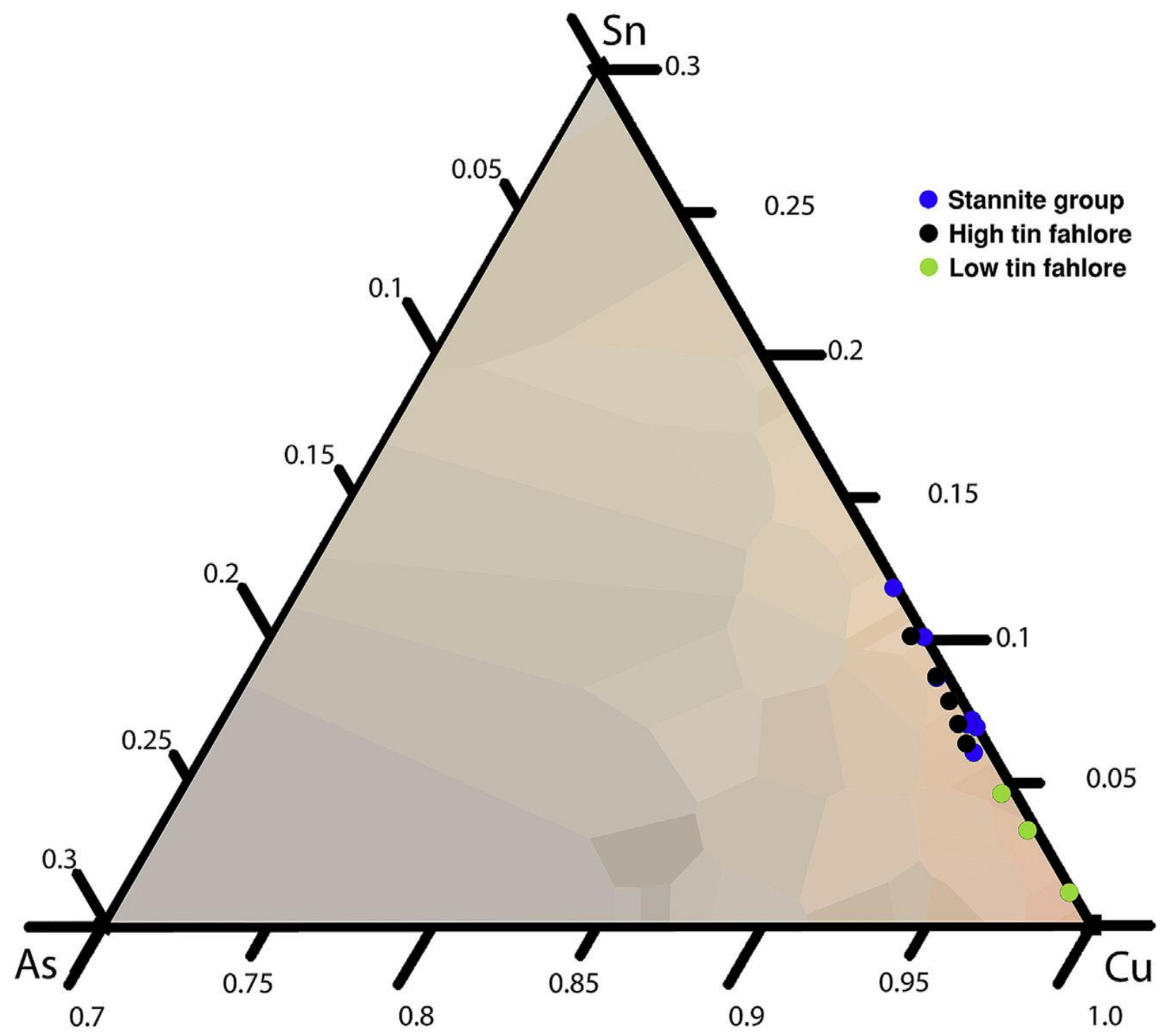

Figure 12 The mid to late 5th millennium BC Balkan bronzes plotted against the Cu-As-Sn ternary colour diagram (100 wt\% Cu $30 w t \%$ As - 30 wt\% Sn corner, see Fig. 8). Fifteen artefacts split into three groups indicate a variety of colour changes,

significantly visible after c. 5 wt\% Sn on the Cu-Sn axis. Data from Radivojević et al. (2013: 1035, Table 1). (For interpretation of the references to colour in this figure legend, the reader is referred to the Web version of this article.) 


\section{Appendix C. Tables}

Table 1 XRF data for Cu-Sn, CU-As and CU-As-Sn binary and ternary alloys, gained and projected values. All values are an average of three measurements per sample. Relative and absolute errors are given in Table 4 (bdl 1/4 below detection limit).

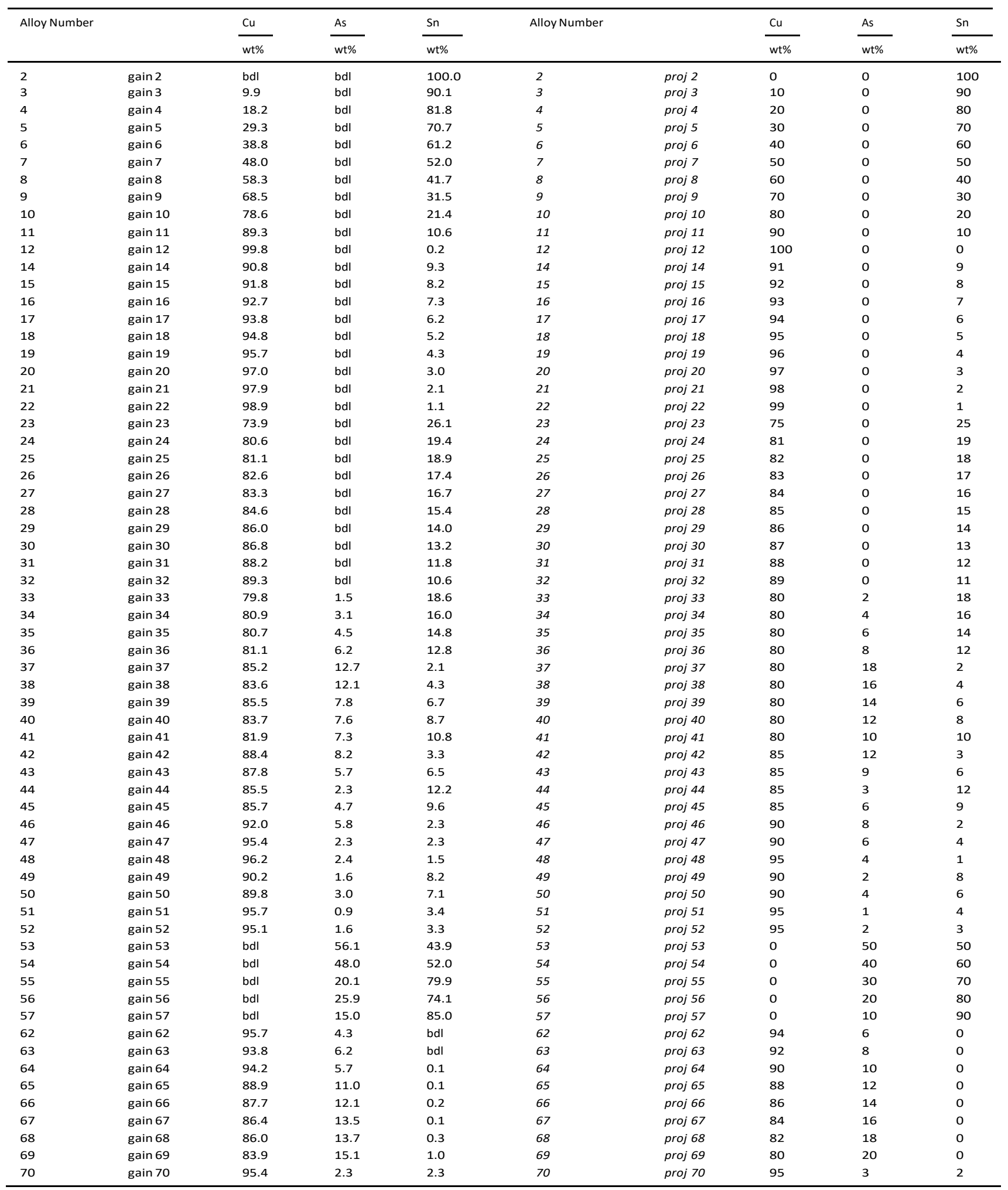


Table 2 Charge components for making binary and ternary alloys in the Cu-As-Sn system (indicated with +).

\begin{tabular}{llllllll}
\hline Group & Alloy & Cu & Sn & As & Cu-Sn & As-Sn & Cu-As \\
\hline I & Cu-Sn & + & + & & & & \\
II & Sn-As & & + & + & & + & \\
III & Cu-As & + & & + & & & + \\
IV & Cu-As-Sn & + & + & + & + & + & \\
\hline
\end{tabular}

Table 3 Projected composition ranges of cast binary and ternary Cu-As-Sn alloys (total of 64).

\begin{tabular}{llccccc}
\hline Group & Alloy & Cu $\%$ & Sn $\%$ & As $\%$ & Alloy numbers & No. of samples \\
\hline I & Cu-Sn & $0-100$ & $0-100$ & - & $2-32$ & 30 \\
II & Sn-As & - & $50-90$ & $10-50$ & $53-57$ & 5 \\
III & Cu-As & $80-94$ & - & $6-20$ & $62-69$ & 8 \\
IV & Cu-As-Sn & $80-95$ & $1-18$ & $1-18$ & $33-52,70$ & 21 \\
\hline
\end{tabular}


Table 4 Compositional analyses (XRF) of metal pellets (gained values) with absolute ( $\Delta$ ) and relative errors ( $\delta)$. While absolute error $(\Delta)$ was calculated as (projected value - gained value), the relative error ( $\delta)$ was produced as (absolute error/gained value). Positive sindicate that gained values are higher than projected (see Table 1), while negative srefers to values lower than the projected.

\begin{tabular}{|c|c|c|c|c|c|c|c|c|c|}
\hline Alloy No gained & $\mathrm{Cu} \%$ & $\Delta \mathrm{Cu}$ & $\delta \mathrm{Cu}$ & As $\%$ & $\Delta \mathrm{As}$ & $\delta$ As & Sn \% & $\Delta \mathrm{Sn}$ & $\delta \mathrm{Sn}$ \\
\hline 2 & 0.0 & 1 & / & 0.0 & I & / & 100.0 & 0.03 & 0.00 \\
\hline 3 & 9.9 & 0.11 & 0.01 & 0.0 & I & / & 90.1 & -0.11 & 0.00 \\
\hline 4 & 18.2 & 1.83 & 0.10 & 0.0 & I & / & 81.8 & -1.83 & -0.02 \\
\hline 5 & 29.3 & 0.73 & 0.02 & 0.0 & I & / & 70.7 & -0.73 & -0.01 \\
\hline 6 & 38.8 & 1.24 & 0.03 & 0.0 & I & / & 61.2 & -1.24 & -0.02 \\
\hline 7 & 48.0 & 2.02 & 0.04 & 0.0 & l & / & 52.0 & -2.02 & -0.04 \\
\hline 8 & 58.3 & 1.70 & 0.03 & 0.0 & I & / & 41.7 & -1.70 & -0.04 \\
\hline 9 & 68.5 & 1.50 & 0.02 & 0.0 & l & / & 31.5 & -1.50 & -0.05 \\
\hline 10 & 78.6 & 1.37 & 0.02 & 0.0 & I & / & 21.4 & -1.37 & -0.06 \\
\hline 11 & 89.34 & 0.66 & 0.01 & 0.0 & l & / & 10.66 & -0.66 & -0.06 \\
\hline 12 & 99.8 & 0.25 & 0.00 & 0.0 & l & / & 0.2 & -0.25 & -1.00 \\
\hline 14 & 90.8 & 0.25 & 0.00 & 0.0 & I & / & 9.3 & -0.25 & -0.03 \\
\hline 15 & 91.8 & 0.18 & 0.00 & 0.0 & I & I & 8.2 & -0.18 & -0.02 \\
\hline 16 & 92.7 & 0.26 & 0.00 & 0.0 & I & I & 7.3 & -0.26 & -0.04 \\
\hline 17 & 93.8 & 0.18 & 0.00 & 0.0 & I & I & 6.2 & -0.18 & -0.03 \\
\hline 18 & 94.8 & 0.20 & 0.00 & 0.0 & I & I & 5.2 & -0.20 & -0.04 \\
\hline 19 & 95.7 & 0.26 & 0.00 & 0.0 & 1 & I & 4.3 & -0.26 & -0.06 \\
\hline 20 & 97.0 & 0.02 & 0.00 & 0.0 & I & I & 3.0 & -0.02 & -0.01 \\
\hline 21 & 97.9 & 0.10 & 0.00 & 0.0 & 1 & / & 2.1 & -0.10 & -0.05 \\
\hline 22 & 98.9 & 0.05 & 0.00 & 0.0 & I & I & 1.1 & -0.05 & -0.05 \\
\hline 23 & 73.9 & 1.08 & 0.01 & 0.0 & I & I & 26.1 & -1.08 & -0.04 \\
\hline 24 & 80.6 & 0.43 & 0.01 & 0.0 & I & I & 19.4 & -0.43 & -0.02 \\
\hline 25 & 81.1 & 0.86 & 0.01 & 0.0 & I & I & 18.9 & -0.86 & -0.05 \\
\hline 26 & 82.6 & 0.43 & 0.01 & 0.0 & 1 & I & 17.4 & -0.43 & -0.02 \\
\hline 27 & 83.3 & 0.73 & 0.01 & 0.0 & I & / & 16.7 & -0.73 & -0.04 \\
\hline 28 & 84.6 & 0.41 & 0.00 & 0.0 & I & / & 15.4 & -0.41 & -0.03 \\
\hline 29 & 86.0 & 0.01 & 0.00 & 0.0 & I & I & 14.0 & -0.01 & 0.00 \\
\hline 30 & 86.8 & 0.20 & 0.00 & 0.0 & I & I & 13.2 & -0.20 & -0.02 \\
\hline 31 & 88.2 & -0.24 & 0.00 & 0.0 & I & I & 11.8 & 0.24 & 0.02 \\
\hline 32 & 89.35 & -0.35 & 0.00 & 0.0 & I & / & 10.65 & 0.35 & 0.03 \\
\hline 33 & 79.8 & 0.19 & 0.00 & 1.5 & 0.45 & 0.29 & 18.6 & -0.64 & -0.03 \\
\hline 34 & 80.9 & -0.91 & -0.01 & 3.1 & 0.93 & 0.30 & 16.0 & -0.02 & 0.00 \\
\hline 35 & 80.7 & -0.69 & -0.01 & 4.5 & 1.49 & 0.33 & 14.8 & -0.80 & -0.05 \\
\hline 36 & 81.1 & -1.09 & -0.01 & 6.2 & 1.85 & 0.30 & 12.8 & -0.76 & -0.06 \\
\hline 37 & 85.2 & -5.19 & -0.06 & 12.7 & 5.31 & 0.42 & 2.1 & -0.12 & -0.06 \\
\hline 38 & 83.6 & -3.56 & -0.04 & 12.1 & 3.87 & 0.32 & 4.3 & -0.31 & -0.07 \\
\hline 39 & 85.5 & -5.45 & -0.06 & 7.8 & 6.20 & 0.79 & 6.7 & -0.74 & -0.11 \\
\hline 40 & 83.7 & -3.70 & -0.04 & 7.6 & 4.43 & 0.59 & 8.7 & -0.73 & -0.08 \\
\hline 41 & 81.9 & -1.94 & -0.02 & 7.3 & 2.72 & 0.37 & 10.8 & -0.78 & -0.07 \\
\hline 42 & 88.4 & -3.43 & -0.04 & 8.2 & 3.77 & 0.46 & 3.3 & -0.34 & -0.10 \\
\hline 43 & 87.8 & -2.83 & -0.03 & 5.7 & 3.33 & 0.59 & 6.5 & -0.50 & -0.08 \\
\hline 44 & 85.5 & -0.47 & -0.01 & 2.3 & 0.66 & 0.28 & 12.2 & -0.19 & -0.02 \\
\hline 45 & 85.7 & -0.68 & -0.01 & 4.7 & 1.29 & 0.27 & 9.6 & -0.60 & -0.06 \\
\hline 46 & 92.0 & -1.96 & -0.02 & 5.8 & 2.22 & 0.39 & 2.3 & -0.26 & -0.12 \\
\hline 47 & 95.4 & -5.40 & -0.06 & 2.3 & 3.73 & 1.65 & 2.3 & 1.67 & 0.72 \\
\hline 48 & 96.2 & -1.17 & -0.01 & 2.4 & 1.63 & 0.69 & 1.5 & -0.46 & -0.32 \\
\hline 49 & 90.2 & -0.24 & 0.00 & 1.6 & 0.43 & 0.27 & 8.2 & -0.19 & -0.02 \\
\hline 50 & 89.8 & 0.17 & 0.00 & 3.0 & 0.96 & 0.31 & 7.1 & -1.13 & -0.16 \\
\hline 51 & 95.7 & -0.74 & -0.01 & 0.9 & 0.13 & 0.15 & 3.4 & 0.60 & 0.18 \\
\hline 52 & 95.1 & -0.08 & 0.00 & 1.6 & 0.39 & 0.24 & 3.3 & -0.31 & -0.09 \\
\hline 53 & 0.0 & 1 & I & 56.1 & -6.08 & -0.11 & 43.9 & 6.10 & 0.14 \\
\hline 54 & 0.0 & 1 & I & 48.0 & -8.02 & -0.17 & 52.0 & 8.03 & 0.15 \\
\hline 55 & 0.0 & 1 & / & 20.1 & 9.93 & 0.49 & 79.9 & -9.93 & -0.12 \\
\hline 56 & 0.0 & 1 & I & 25.9 & -5.87 & -0.23 & 74.1 & 5.89 & 0.08 \\
\hline 57 & 0.0 & 1 & / & 15.0 & -4.97 & -0.33 & 85.0 & 4.97 & 0.06 \\
\hline 62 & 95.7 & -1.69 & -0.02 & 4.3 & 1.73 & 0.40 & 0.0 & 1 & / \\
\hline 63 & 93.8 & -1.76 & -0.02 & 6.2 & 1.81 & 0.29 & 0.0 & I & / \\
\hline 64 & 94.2 & -4.22 & -0.04 & 5.7 & 4.32 & 0.76 & 0.1 & 1 & I \\
\hline 65 & 88.9 & -0.88 & -0.01 & 11.0 & 0.97 & 0.09 & 0.1 & I & I \\
\hline 66 & 87.7 & -1.74 & -0.02 & 12.1 & 1.91 & 0.16 & 0.2 & I & / \\
\hline 67 & 86.4 & -2.37 & -0.03 & 13.5 & 2.50 & 0.19 & 0.1 & I & I \\
\hline 68 & 86.0 & -4.03 & -0.05 & 13.7 & 4.31 & 0.31 & 0.3 & 1 & / \\
\hline 69 & 83.9 & -3.93 & -0.05 & 15.1 & 4.92 & 0.33 & 1.0 & -1.00 & -1.00 \\
\hline 70 & 95.4 & -0.41 & 0.00 & 2.3 & 0.72 & 0.31 & 2.3 & -0.31 & -0.14 \\
\hline
\end{tabular}


Table 5 Colorimetric values for all binary and ternary CU-As-Sn alloys, given as $L^{*}, a^{*}, b^{*}$ and their conversion to RGB. Please note that No. 71 refers to pure As metal, which we did not measure for colorimetry, but sampled RGB values from a web image of pure As metal (see footnote 3 ).

\begin{tabular}{|c|c|c|c|c|c|c|}
\hline Alloy No. & $L^{*}$ & $a^{*}$ & $b^{*}$ & $R$ & G & B \\
\hline 2 & 88.59 & 0.11 & 6.71 & 228 & 222 & 210 \\
\hline 3 & 84.67 & -0.13 & 6.27 & 216 & 211 & 200 \\
\hline 4 & 87.43 & 0.27 & 4.52 & 223 & 219 & 211 \\
\hline 5 & 85.98 & 0.36 & 3.94 & 219 & 214 & 208 \\
\hline 6 & 85.08 & 0.25 & 3.63 & 216 & 212 & 206 \\
\hline 7 & 85.18 & 0.10 & 2.88 & 215 & 212 & 207 \\
\hline 8 & 81.33 & 0.86 & 2.11 & 205 & 201 & 198 \\
\hline 9 & 84.43 & 1.42 & 6.13 & 218 & 209 & 199 \\
\hline 10 & 85.81 & 3.55 & 12.45 & 231 & 212 & 191 \\
\hline 11 & 85.28 & 8.13 & 17.97 & 241 & 207 & 180 \\
\hline 12 & 81.35 & 15.62 & 18.63 & 243 & 191 & 168 \\
\hline 14 & 86.24 & 8.28 & 17.10 & 244 & 209 & 184 \\
\hline 15 & 86.02 & 9.26 & 17.32 & 245 & 208 & 183 \\
\hline 16 & 84.77 & 10.27 & 18.35 & 244 & 204 & 178 \\
\hline 17 & 84.74 & 10.53 & 17.44 & 243 & 204 & 179 \\
\hline 18 & 83.24 & 11.62 & 18.22 & 241 & 199 & 174 \\
\hline 19 & 82.41 & 12.60 & 17.28 & 240 & 196 & 173 \\
\hline 20 & 84.39 & 12.53 & 17.86 & 246 & 201 & 178 \\
\hline 21 & 84.27 & 12.81 & 17.14 & 246 & 201 & 179 \\
\hline 22 & 83.29 & 14.30 & 16.98 & 245 & 197 & 176 \\
\hline 23 & 83.76 & 2.57 & 10.47 & 222 & 207 & 189 \\
\hline 24 & 87.06 & 3.09 & 11.99 & 233 & 215 & 196 \\
\hline 25 & 85.01 & 4.11 & 13.90 & 231 & 209 & 186 \\
\hline 26 & 86.71 & 4.23 & 13.71 & 236 & 214 & 191 \\
\hline 27 & 87.82 & 4.52 & 13.75 & 239 & 216 & 194 \\
\hline 28 & 87.71 & 4.66 & 13.63 & 239 & 216 & 194 \\
\hline 29 & 87.39 & 5.62 & 14.53 & 241 & 215 & 192 \\
\hline 30 & 86.46 & 5.45 & 14.30 & 238 & 212 & 190 \\
\hline 31 & 88.07 & 6.71 & 15.02 & 245 & 216 & 193 \\
\hline 32 & 87.45 & 7.17 & 14.75 & 244 & 214 & 192 \\
\hline 33 & 85.95 & 2.98 & 10.09 & 229 & 212 & 196 \\
\hline 34 & 85.08 & 2.78 & 9.78 & 226 & 210 & 194 \\
\hline 35 & 84.79 & 2.86 & 10.29 & 225 & 209 & 193 \\
\hline 36 & 83.26 & 2.58 & 8.59 & 219 & 205 & 191 \\
\hline 37 & 75.82 & 2.62 & 7.35 & 198 & 185 & 173 \\
\hline 38 & 80.87 & 2.25 & 6.33 & 210 & 199 & 189 \\
\hline 39 & 84.37 & 3.05 & 8.44 & 223 & 208 & 195 \\
\hline 40 & 83.25 & 2.71 & 9.30 & 220 & 205 & 190 \\
\hline 41 & 81.93 & 2.43 & 8.76 & 215 & 202 & 187 \\
\hline 42 & 81.64 & 3.70 & 9.15 & 217 & 200 & 186 \\
\hline 43 & 82.62 & 4.10 & 10.66 & 222 & 202 & 186 \\
\hline 44 & 85.85 & 4.37 & 11.91 & 232 & 211 & 192 \\
\hline 45 & 84.96 & 3.84 & 10.02 & 227 & 209 & 194 \\
\hline 46 & 84.23 & 5.77 & 11.20 & 230 & 206 & 189 \\
\hline 47 & 84.64 & 9.25 & 15.09 & 240 & 204 & 183 \\
\hline 48 & 84.28 & 9.15 & 14.42 & 238 & 204 & 184 \\
\hline 49 & 85.16 & 7.16 & 15.29 & 237 & 207 & 184 \\
\hline 50 & 84.35 & 6.57 & 13.74 & 233 & 205 & 185 \\
\hline 51 & 84.49 & 11.08 & 17.65 & 244 & 203 & 178 \\
\hline 52 & 84.81 & 9.22 & 15.60 & 240 & 205 & 183 \\
\hline 53 & 80.97 & 0.01 & 0.86 & 202 & 201 & 199 \\
\hline 54 & 82.63 & -0.07 & 1.00 & 206 & 206 & 204 \\
\hline 55 & 84.72 & 0.12 & 2.17 & 214 & 211 & 207 \\
\hline 56 & 86.96 & -0.02 & 1.39 & 219 & 218 & 215 \\
\hline 57 & 86.64 & -0.19 & 3.65 & 220 & 217 & 210 \\
\hline 62 & 81.10 & 8.29 & 15.32 & 228 & 195 & 173 \\
\hline 63 & 80.25 & 5.38 & 11.46 & 218 & 195 & 178 \\
\hline 64 & 81.44 & 5.04 & 10.49 & 220 & 199 & 183 \\
\hline 65 & 81.92 & 3.21 & 6.28 & 215 & 201 & 192 \\
\hline 66 & 81.09 & 3.00 & 6.66 & 212 & 199 & 189 \\
\hline 67 & 76.91 & 2.23 & 5.67 & 199 & 188 & 180 \\
\hline 68 & 79.90 & 2.33 & 5.04 & 206 & 196 & 189 \\
\hline 69 & 79.09 & 2.09 & 4.55 & 204 & 194 & 188 \\
\hline 70 & 84.39 & 9.36 & 15.62 & 239 & 204 & 182 \\
\hline 71 & & & & 202 & 212 & 217 \\
\hline
\end{tabular}

